\title{
Bottomset and foreset sedimentary processes in the mixed carbonate-siliciclastic Upper Jurassic-Lower Cretaceous Vaca Muerta Formation, Picún Leufú Area, Argentina
}

\author{
Maximiliano Paz ${ }^{\mathrm{a}, *}$, Juan José Ponce ${ }^{\mathrm{b}}$, Luis A. Buatois ${ }^{\mathrm{a}}$, M. Gabriela Mángano ${ }^{\mathrm{a}}$, Noelia Beatriz Carmona ${ }^{\mathrm{b}}$, \\ Egberto Pereira ${ }^{c}$, Patricio R. Desjardins ${ }^{\mathrm{d}}$ \\ a Department of Geological Sciences, University of Saskatchewan, 114 Science Place, S7N 5E2 Saskatoon, Canada \\ b Instituto de Investigación en Paleobiología y Geología, CONICET-Universidad Nacional de Río Negro, Av. Roca 1242, R8332EXZ General Roca, Argentina

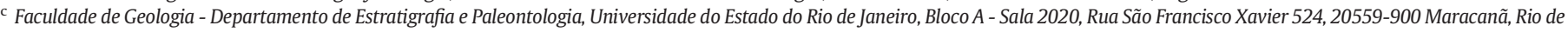 \\ Janeiro, Brazil \\ d Shell Exploration and Production Company, 200N Dairy Ashford St, Houston, TX 77019, USA
}

\section{A R T I C L E I N F O}

\section{Article history:}

Received 9 March 2019

Received in revised form 20 June 2019

Accepted 23 June 2019

Available online 26 June 2019

Editor: Dr. B. Jones

\section{Keywords:}

Wave-influenced hyperpycnal flows

Bioturbation

Neuquén Basin

Fine-grained systems

Unconventional reservoirs

\begin{abstract}
A B S T R A C T
The Upper Jurassic-Lower Cretaceous Vaca Muerta Formation at the Picún Leufú area constitutes bottomset and foreset marine deposits comprising open bay, siliciclastic basin and mixed carbonate-siliciclastic shelf facies. Detailed sedimentological, ichnological and sequence stratigraphic analysis of six stratigraphic sections allows establishing two depositional sequences. Depositional Sequence 1 (DS1) begins with lowstand eolian deposits included in the Quebrada del Sapo Formation, and continues with thin, retrograding, transgressive open bay facies of the Vaca Muerta Formation encompassing coastal sand sheet and dune, marginal marine, bay margin and distal bay facies. Above the transgressive deposits, the regressive hemicycle of DS1 consists of bottomset deposits representing a siliciclastic basin facies association. Lobe and lobe fringe hyperpycnal flow sedimentation alternated with hemipelagic basinal deposition in an oxygen-deficient environment. A relative sea-level fall generated a sequence boundary, which coincides with an angular unconformity that marks the base of Depositional Sequence 2 (DS2). This sea-level fall triggered the formation of an extensive lowstand channel-fill and lobe complex at the base of the slope, followed by retrogradational lobe facies during the subsequent transgression. The regressive hemicycle of DS2 represents foreset mixed carbonate-siliciclastic shelf facies, forming a slope mud belt and slope sand bodies. Near the top, sedimentation in a foreset-topset transition resulted in the accumulation of bioturbated mixed slope and sandy shoal deposits. Sand bars and lagoonal facies occur on top of all sections and are truncated by a sequence boundary. The combined analysis provides insights into the sedimentary processes affecting bottomset and foreset deposition, underscoring the role of wave-influenced hyperpycnal flows, and the effect on organic matter dilution in one of the most important unconventional reservoirs from Argentina.
\end{abstract}

(C) 2019 Elsevier B.V. All rights reserved.

\section{Introduction}

Clinoform-shaped deposits are found in deltas, shelves and carbonate environments, and their analysis aids to identify sea-level variations which in turn are key for sequence stratigraphic interpretations (Steel and Olsen, 2002; Helland-Hansen and Hampson, 2009). Systems showing clinothems (i.e. clinoform-shaped rocks) typically encompass three

\footnotetext{
* Corresponding author.

E-mail addresses: maxi.paz@usask.ca (M. Paz),jponce@unrn.edu.ar (J.J. Ponce), luis.buatois@usask.ca (L.A. Buatois), gabriela.mangano@usask.ca (M.G. Mángano), ncarmona@unrn.edu.ar (N.B. Carmona), egberto@uerj.br (E. Pereira), p.desjardins@shell.com (P.R. Desjardins).
}

distinctive depositional areas: topset, foreset and bottomset (Gilbert, 1885; Bates, 1953; Pirmez et al., 1998; Steel and Olsen, 2002; Swenson et al., 2005; Patruno et al., 2015). The Upper Jurassic-Lower Cretaceous Vaca Muerta Formation of the Neuquén Basin, Argentina, consists of mudstone, marl and limestone representing a mixed carbonate-siliciclastic shelf showing well-developed bottomset to foreset strata, overlain by topset carbonate deposits of the Picún Leufú Formation. This unit shows an intermediate paleogeomorphology varying between sloping foreset, rimmed shelves and slope-absent ramps (see Williams et al., 2011). Mitchum and Uliana (1985) highlighted the importance of basin, slope and shelf positions as distinctive depositional areas of the Vaca Muerta Formation comparable to bottomset, foreset and topset areas. Later, several workers continued 
differentiating these segments for sequence stratigraphic interpretations (e.g. Reijenstein et al., 2014; Domínguez et al., 2014; Desjardins et al., 2016), incorporating new techniques (Zeller, 2013; Zeller et al., 2014, 2015a) and recognizing their plain-view geometry (Dominguez et al., 2017). All of these efforts are useful for understanding depositional environments and sedimentary processes in each segment of the depositional system.

Several studies focused on the most prolific Central Neuquén Basin area (González et al., 2016 and references therein), where carbonaterich facies were deposited. In contrast, siliciclastic-dominated facies occur in the Picún Leufú area, where well-exposed outcrops of the Vaca Muerta-Picún Leufú mixed system occur. The Picún Leufú area is located in the NW area of the Picún Leufú depocenter (Fig. 1), comprising a distinctive sub-basin located at the south of the east-west trending Huincul Ridge structural system that divides the Neuquén Basin at its $39^{\circ} \mathrm{S}$ latitude. An east-west anticline exposes the clinoform geometries of the formation and represents an exceptional opportunity to study the relationship between foreset and bottomset sedimentary facies in mixed depositional environments. The objective of this study is to integrate the sedimentological, ichnological, and sequence stratigraphic datasets of the Vaca Muerta Formation in the Picún Leufú area, to construct a depositional model. The proposed model has implications for understanding bottomset and foreset sedimentary processes, with a particular emphasis on the importance of wave-influenced hyperpycnal flows for bottomset sedimentation and organic matter dilution.

\section{Geological setting}

The Neuquén Basin constitutes a triangular-shaped basin located in western-central Argentina, bounded by cratonic areas at the northeast and southeast margins and by the Andean magmatic arc at the west. The stratigraphic record of this basin consists of approximately $7000 \mathrm{~m}$ of Jurassic and Cretaceous strata deposited since Late TriassicEarly Jurassic times (Arregui et al., 2011). Tectonics controlled basin development, and its evolution can be subdivided in three different stages, namely syn-rift, back-arc (post-rift) and foreland stage (Howell et al., 2005). The syn-rift phase occurs during the Late Triassic to Early Jurassic

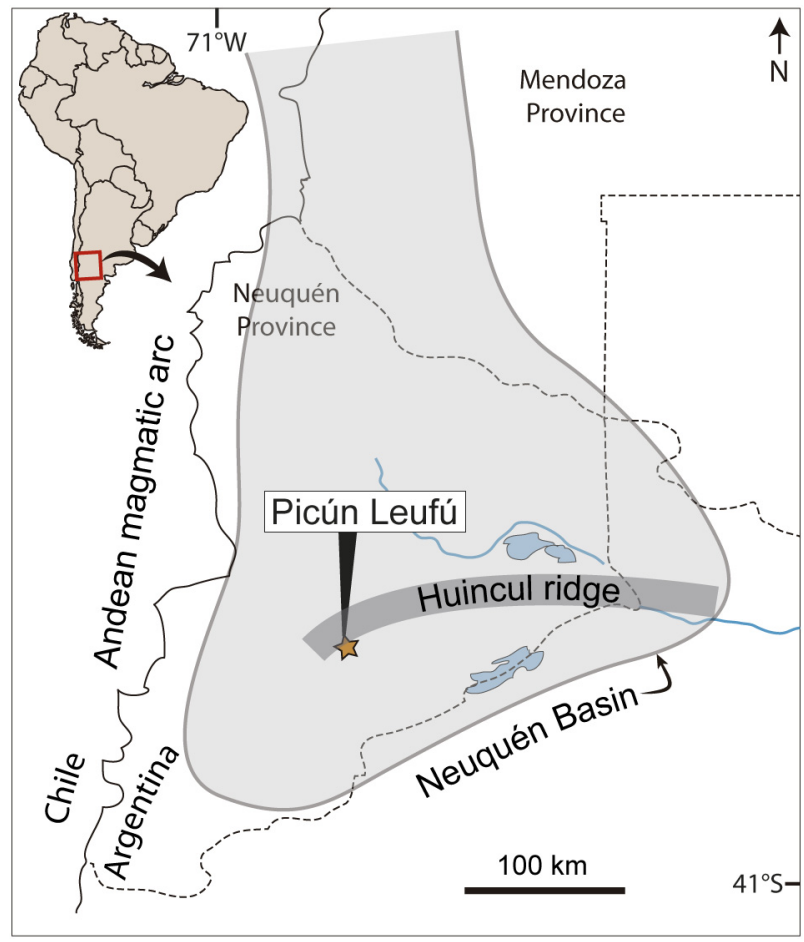

Fig. 1. General map showing location of the study area.
(Gulisano, 1981; Carbone et al., 2011). During the Early Jurassic, subduction in the active western margin of Gondwana generated a magmatic arc (Mpodozis and Ramos, 2008) and a subsequent shift to a back-arc basin stage. Since this time and up to the Early Cretaceous, alternating marine and continental sedimentation as a response to relative sealevel fluctuations was recorded by the Cuyo, Lotena and Mendoza groups. A Late Cretaceous compressional tectonic regime led to the closure of the connection with the Pacific Ocean and the establishment of the foreland stage (Ramos and Folguera, 2005; Tunik et al., 2010).

The Vaca Muerta Formation comprises upper lower Tithonian to lower Valanginian marine deposits of the Mendoza Group (Stipanicic et al., 1968) and records one of the back-arc stage transgression pulses of the Pacific Ocean over continental deposits (Leanza et al., 2011). It is mainly composed by mudstone, marl and limestone that are commonly referred to as black shales due to their high organic matter content (3-8\% TOC with upper values of $10-12 \%$, Uliana et al., 1999). The Vaca Muerta Formation is grouped into the Lower Mendoza Mesosequence (Fig. 2, Legarreta and Gulisano, 1989), a sequence stratigraphic subdivision bounded at the base and top by the intra-Malmic and intra-Valanginian unconformities, respectively. This mesosequence starts with the establishment of the Tordillo Formation continental deposits and their lateral equivalents, which are covered by the Vaca Muerta Formation offshore deposits (Legarreta and Gulisano, 1989). At the top, the Vaca Muerta Formation has a transitional and diachronic contact with the overlying nearshore deposits of the Quintuco Formation and their lateral equivalents, such as the Picún Leufú Formation (Legarreta and Gulisano, 1989). The intra-Valanginian unconformity marks the end of the Lower Mendoza Mesosequence by a relative sealevel fall (Gulisano et al., 1984).

\subsection{The Picún Leufú anticline and Quebrada del Sapo areas}

The Picún Leufú study area comprises the northwestern part of the Picún Leufú depocenter and the westernmost edge of the Huincul ridge system (Fig. 1). The area shows the convergence of two Huincul ridge structures: a south-verging, east-west anticline affecting the Cuyo, Lotena and Mendoza groups, namely the Picún Leufú anticline, and a NNE-oriented ravine associated with the Sierra de Chacaico anticline, known as Quebrada del Sapo (Fig. 3).

The stratigraphy of the Lower Mendoza Mesosequence in the study area is represented by the Quebrada del Sapo, Vaca Muerta and Picún Leufú formations (Fig. 2). The Quebrada del Sapo Formation (Digregorio, 1972) is regarded as Kimmeridgian in age based on its lithostratigraphic correlation with the Tordillo Formation (Veiga and Spalletti, 2007), although evidence of an unconformity between these two units has been suggested, indicating that the Quebrada del Sapo Formation may be younger (Zavala et al., 2008). Sedimentological and stratigraphic studies indicate that this formation consists of conglomerate, sandstone and mudstone deposited in fluvial, eolian (Veiga and Spalletti, 2007) and lacustrine systems (Zavala et al., 2005).

The Vaca Muerta Formation overlays the Quebrada del Sapo Formation by a sharp to erosive transgressive surface. The contact between the Vaca Muerta and the overlying Picún Leufú formations is gradational. An early Tithonian-early Berrasian age based in ammonite zones has been assigned for this system in the Picún Leufú area (Leanza and Hugo, 1977).

Several sedimentological and sequence stratigraphic studies focusing on different intervals of these two lithostratigraphic units have been conducted in this area (Leanza, 1973; Spalletti et al., 2000; Freije et al., 2002; Zavala and Freije, 2002; Armella et al., 2007; Zeller, 2013; Massaferro et al., 2014; Zeller et al., 2014, 2015b; Otharán et al., 2016, 2017; Ponce et al., 2015, 2016; Krim et al., 2017). Summarizing all the previous studies, the Vaca Muerta and Picún Leufú formations constitute a mixed carbonate-siliciclastic system, the first one being the seaward siliciclastic equivalent of the latter. Initially Spalletti et al. (2000) suggested the development of two shallowing-upwards sequences of 


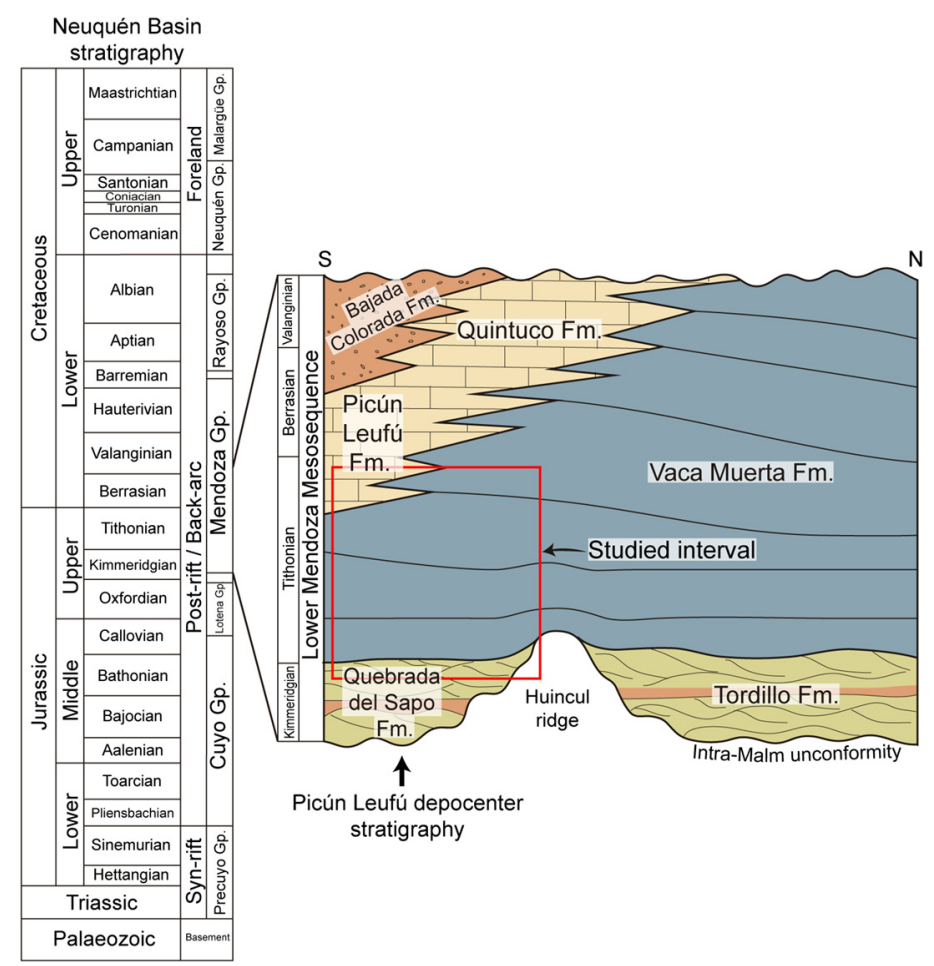

Fig. 2. Neuquén Basin and Picún Leufú depocenter stratigraphy, with an S-N section of the Lower Mendoza Mesosequence locating the studied interval. (Modified from Howell et al. (2005).)

a tidally-influenced siliciclastic carbonate system. Zeller (2013) interpreted this interval as a mixed carbonate-siliciclastic succession with the Vaca Muerta Formation comprising one third-order transgressive-regressive succession (Massaferro et al., 2014; Zeller et al., 2015b). Otharán et al. (2016, 2017) emphasized siliciclastic sedimentation by turbidity currents and hyperpycnal flows at slope and offshore positions, with the development of two third-order sequences. The last interpretation implies a siliciclastic shelf and a mixed ramp arranged in two low-frequency transgressive-regressive sequences (Krim et al., 2017). These papers added plenty of sedimentological information to the study area, yet the hyperpycnal deposits are still poorly documented.

The Picún Leufú anticline records successive pulses of growth since the Early Jurassic and up to the Early Cretaceous, represented in outcrop by growth unconformities and thickness changes (Freije et al., 2002; Zavala and Freije, 2002; Naipauer et al., 2012). Kimmeridgian to middle Tithonian (lower A. proximus ammonite zone of Parent et al., 2011) synsedimentary deformation affected from east to west the Lower
Mendoza Mesosequence in the Picún Leufú anticline, whereas in Quebrada del Sapo the stratum is almost undeformed. Deformational events caused normal faults and progressive unconformities within this mesosequence. The syn-sedimentary normal faults crosscut the uppermost part of the Quebrada del Sapo Formation dune deposits and up to $\sim 50 \mathrm{~m}$ of the lowermost Vaca Muerta Formation. The progressive unconformity represents a deformational event showing a gradual decrease in dip in the Quebrada del Sapo Formation and the lowermost $\sim 80-120$ m of the Vaca Muerta Formation. On top of the progressive unconformity, an angular unconformity occurs within the Vaca Muerta Formation, represented by change of dips of $15^{\circ}-40^{\circ}$ in the strata below, to $7^{\circ}-30^{\circ}$ in the strata on top, and suggesting a dip difference of $10^{\circ}$ in sections 4,3 and 2, to $23^{\circ}$ near section 5 (Fig. 4). Dips on top of the unconformity remain constant, indicating the end of the progressive unconformity affecting the anticline. A post-sedimentation deformational event is responsible for an additional $\sim 7-30^{\circ}$ tilting in the whole succession, showing its maximum expression to the east of the anticline and decreasing towards the west (Quebrada del Sapo).

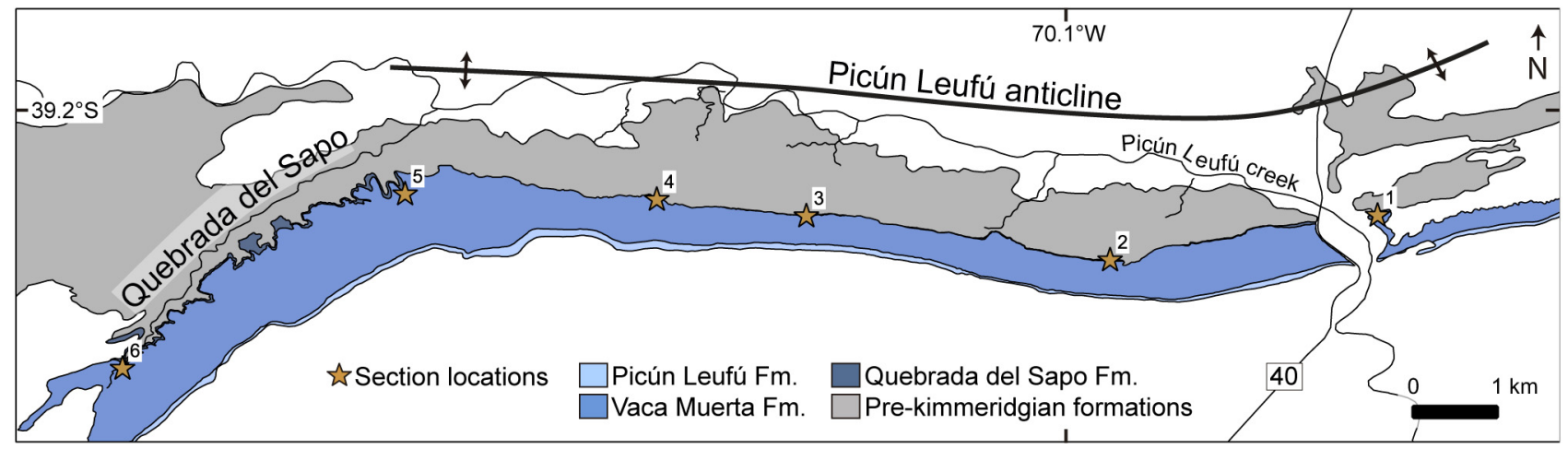

Fig. 3. Map of the study area showing location of the measured sections. 


\section{Methodology}

Sedimentological and ichnological analysis was carried on in six stratigraphic sections of the Vaca Muerta Formation (230-330 m) and part of the Picún Leufú Formation ( $30 \mathrm{~m})$. Two of the six bed-by-bed stratigraphic sections were measured in Quebrada del Sapo and four in the Picún Leufú anticline (Fig. 3). Twenty five samples were taken to analyze lithofacies in thin section under petrographic microscope. Total organic carbon (TOC) analysis (52 samples) were performed using LECO SC 632 at the Laboratório de Estratigrafia Química e Geoquímica Orgânica of the Universidade do Estado do Rio de Janeiro, Brazil. The fine-grained siliciclastic and carbonate rocks were classified according to Lazar et al. (2015) and Wright (1992), respectively. The ichnological analysis consists of the description of ichnotaxa and assessment of ethologies, ichnodiversity and degree of bioturbation (from 0 to 6, after Taylor and Goldring, 1993). For the sequence stratigraphic analysis, Google Earth imagery was analyzed together with a published seismic line parallel to our section and distant $10 \mathrm{~km} \mathrm{SE}$ (Zeller, 2013; Massaferro et al., 2014) to understand stratal geometry and to visualize large-scale stratal terminations.

\section{Sedimentary facies}

Integration of sedimentological and ichnological information allowed recognition of twelve facies grouped into three facies assemblages (Table 1, Fig. 5).

\subsection{Facies assemblage $A(F A A)$}

\subsubsection{Facies 1 (F1)}

This facies consists of sharp-based, thin- to medium-bedded (3-20 cm-thick), low-angle cross-bedded to horizontal-bedded, medium-grained sandstone (Fig. 6a, b). Asymmetrical and minor symmetrical ripples are commonly seen on bedding planes. The low-angle cross-bedding shows dips towards ESE and WSW, and minor towards $\mathrm{N}$ and $\mathrm{NE}$, whereas current ripples have paleocurrents towards $S$ and WNW. A thin $(\ll 0.5 \mathrm{~m})$ interval of erosive-based, trough cross-stratified sandstone is observed below the low-angle lithofacies, displaying a patchy distribution, and locally showing organic matter drapes. F1 locally shows water escape structures. F1 is $0.5-2 \mathrm{~m}$ thick, and has a largescale tabular geometry. This facies occurs in the easternmost and in the Quebrada del Sapo sections, where the Quebrada del Sapo Formation eolian deposits show the thicker succession.

F1 records sedimentation in coastal sand sheet and dunes associated with a shallow groundwater table. Low-angle cross bedding suggests low-relief bedforms that were later reworked into rippled surfaces by frequent tidal flooding (e.g. Fryberger et al., 1990). The current ripples are produced by water-lain sedimentation, whereas the symmetrical ripples indicate wave reworking in a high water-table environment. Eolian processes were also active, and the patchy trough crossbedded sandstone reflects thin coastal dune construction. The water escape structures suggest soft-sediment deformation in water-saturated sands.

\subsubsection{Facies 2 (F2)}

This facies consists of a bindstone interval of $5-30 \mathrm{~cm}$ thick (Fig. 6a, b). TOC is high ( mean $=20.15 \%, N=2$ ). In thin section, the bindstone shows an alternation of sandstone-rich and organic matter laminae with a wavy to lenticular pattern. The organic matter laminae contain grains displaying a preferential orientation of their major axes, which are arranged parallel to the pseudo-lamination. Ammonite molds and bivalve shells occur intercalated in the bindstone. This facies overlies the Quebrada del Sapo eolian dune deposits or F1 by a sharp surface.

Facies 2 resulted from microbial mat vertical accretion in a lowenergy, marginal marine area subject to stress conditions. The laminae showing wavy to lenticular pattern representing a wavy-crinkly laminated structure (Schieber, 1986, 2007) and the oriented grain texture and pyrite in the lamination indicate a microbial mat origin (Noffke, 2010).

\subsubsection{Facies 3 (F3)}

This facies is composed by cycles of thin-bedded $(1-10 \mathrm{~cm})$, carbonaceous-calcareous medium mudstone, bioclastic wackestone and packstone. Symmetrical ripples are locally preserved on top of the cycles. TOC content is moderate (mean $=2.01 \%, N=2$ ), with one high value of $17 \%$. Locally, thin-bedded $(1-5 \mathrm{~cm})$, muddy heterolithic
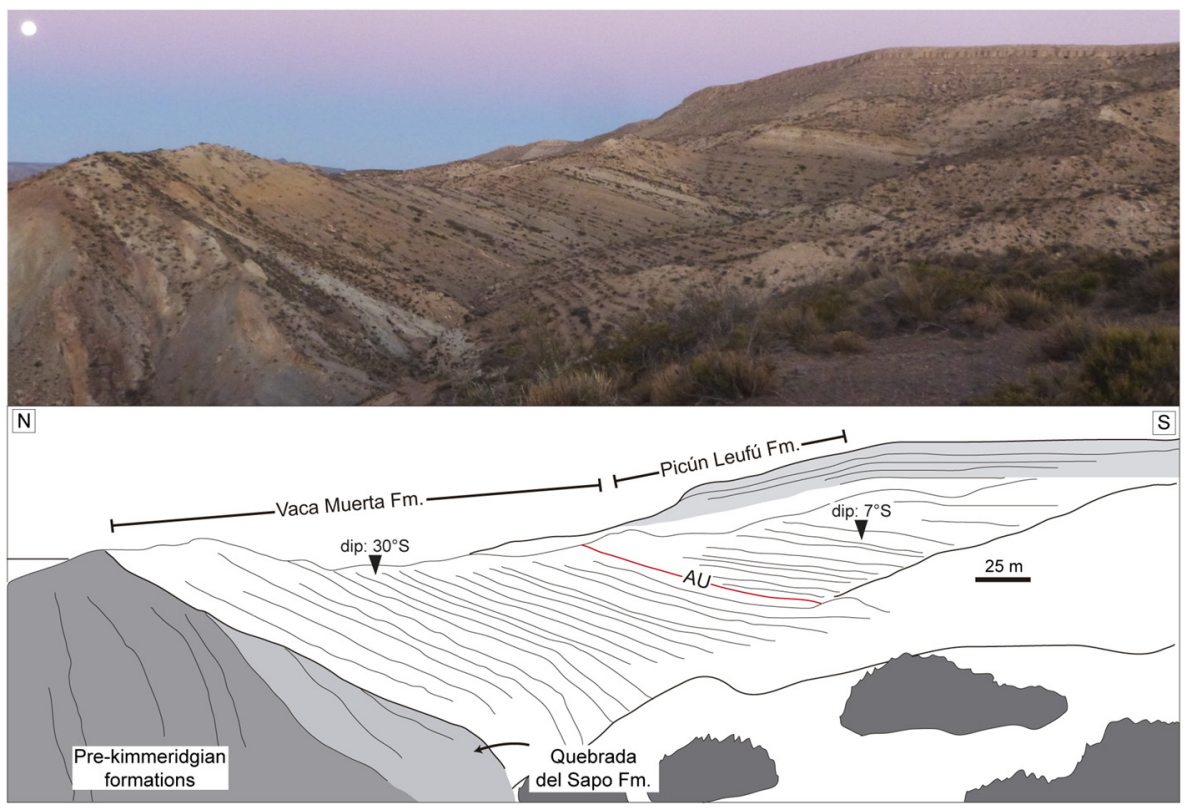

Fig. 4. Angular unconformity (AU) observed in areas close to section 5 (see Fig. 3 for location). Dip data shows angle and dip direction. 
Table 1

Open bay, siliciclastic basin and mixed carbonate-siliciclastic shelf sedimentary facies of the Vaca Muerta Formation in the Picún Leufú area.

\begin{tabular}{|c|c|c|c|c|c|c|c|c|}
\hline Facies & $\begin{array}{l}\text { Bedding } \\
\text { thickness }\end{array}$ & Geometry & Lithology & $\begin{array}{l}\text { Sedimentary } \\
\text { structures }\end{array}$ & Ichnology & $\begin{array}{l}\text { Fossil } \\
\text { content }\end{array}$ & Interpretation & $\begin{array}{l}\text { Distribution in } \\
\text { the section }\end{array}$ \\
\hline $\begin{array}{l}\text { F1: Coastal sand } \\
\text { sheet and dune }\end{array}$ & $3-20 \mathrm{~cm}$ & Tabular & $\begin{array}{l}\text { Medium-grained } \\
\text { sandstone }\end{array}$ & $\begin{array}{l}\text { Low-angle } \\
\text { cross-bedding to } \\
\text { horizontal-bedding. } \\
\text { Symmetrical and } \\
\text { asymmetrical } \\
\text { ripples on bedding } \\
\text { surfaces }\end{array}$ & Unbioturbated & - & $\begin{array}{l}\text { Sand sheet and } \\
\text { low-relief } \\
\text { bedforms } \\
\text { associated with } \\
\text { eolian } \\
\text { sedimentation } \\
\text { in a high water } \\
\text { table } \\
\text { environment }\end{array}$ & $\begin{array}{l}\text { At the base of } \\
\text { the Formation, } \\
\text { in areas with } \\
\text { eolian deposits }\end{array}$ \\
\hline F2: Mud flat & $5-30 \mathrm{~cm}$ & Tabular & Bindstone & $\begin{array}{l}\text { Wavy-crinkly } \\
\text { lamination }\end{array}$ & Unbioturbated & $\begin{array}{l}\text { Ammonites } \\
\text { and bivalves }\end{array}$ & $\begin{array}{l}\text { Coastal mud flat } \\
\text { accretion in } \\
\text { stressed } \\
\text { environments }\end{array}$ & $\begin{array}{l}\text { At the Formation } \\
\text { base, after the } \\
\text { transgressive } \\
\text { surface. }\end{array}$ \\
\hline F3: Bay margin & $1-10 \mathrm{~cm}$ & $\begin{array}{l}\text { Large-scale } \\
\text { thickness } \\
\text { variation }\end{array}$ & $\begin{array}{l}\text { Medium mudstone, } \\
\text { bioclastic wackestone and } \\
\text { packstone }\end{array}$ & Wave ripples & $\begin{array}{l}\text { Poorly-defined } \\
\text { biodeformational } \\
\text { structures (BI = } \\
\text { 4-6), crosscut by } \\
\text { Thalassinoides isp. }\end{array}$ & $\begin{array}{l}\text { Fragmented } \\
\text { ammonite } \\
\text { molds and } \\
\text { bivalve } \\
\text { shells }\end{array}$ & $\begin{array}{l}\text { Wave } \\
\text { reworking in a } \\
\text { low-energy } \\
\text { environment } \\
\text { showing } \\
\text { stressed } \\
\text { conditions }\end{array}$ & $\begin{array}{l}\text { At the Formation } \\
\text { base or on top of } \\
\text { facies F2, in a } \\
\text { retrogradational } \\
\text { succession }\end{array}$ \\
\hline F4: Distal bay & $5-20 \mathrm{~cm}$ & $\begin{array}{l}\text { Large-scale } \\
\text { thickness } \\
\text { variation }\end{array}$ & $\begin{array}{l}\text { Medium mudstone, with } \\
\text { minor medium-grained } \\
\text { sandstone and tuff }\end{array}$ & $\begin{array}{l}\text { Normal gradation in } \\
\text { the sandstone }\end{array}$ & $\begin{array}{l}\text { Highly bioturbated, } \\
\text { displaying } \\
\text { Thalassinoides isp., } \\
\text { Palaeophycus } \\
\text { tubularis and } \\
\text { Teichichnus rectus } \\
\text { and } \\
\text { biodeformational } \\
\text { structures } \\
\text { Ichnodiversity is } \\
\text { low and } \\
\text { bioturbation index } \\
\text { is 2-3 }\end{array}$ & $\begin{array}{l}\text { Bivalve, } \\
\text { ammonite } \\
\text { and } \\
\text { gastropod } \\
\text { shells }\end{array}$ & $\begin{array}{l}\text { Deposition } \\
\text { below } \\
\text { fair-weather } \\
\text { wave base. } \\
\text { Intercalation of } \\
\text { muddy } \\
\text { tempestites and } \\
\text { sandy } \\
\text { concentrated } \\
\text { density flow } \\
\text { deposits }\end{array}$ & $\begin{array}{l}\text { On top of facies } \\
\text { F3, in a } \\
\text { retrogradational } \\
\text { succession }\end{array}$ \\
\hline $\begin{array}{l}\text { F5: } \\
\text { Sediment-starved } \\
\text { basin }\end{array}$ & $1 \mathrm{~m}$ & Tabular & $\begin{array}{l}\text { Carbonaceous-argillaceous } \\
\text { fine mudstone to } \\
\text { argillaceous medium } \\
\text { mudstone, minor thin, } \\
\text { massive fine mudstone }\end{array}$ & $\begin{array}{l}\text { Parallel-lamination, } \\
\text { slumps, sand dykes } \\
\text { and } \\
\text { syn-sedimentary } \\
\text { faults }\end{array}$ & Unbioturbated & $\begin{array}{l}\text { Pectinid } \\
\text { bivalves, } \\
\text { ammonites, } \\
\text { plant debris } \\
\text { and fish } \\
\text { scales }\end{array}$ & $\begin{array}{l}\text { Organic carbon } \\
\text { enrichment due } \\
\text { to low } \\
\text { sedimentary } \\
\text { input from } \\
\text { hemipelagic } \\
\text { and eolian } \\
\text { deposition, } \\
\text { minor buoyant } \\
\text { plume } \\
\text { deposition }\end{array}$ & $\begin{array}{l}\text { Above facies F4, } \\
\text { in bottomset } \\
\text { areas }\end{array}$ \\
\hline $\begin{array}{l}\text { F6a: Hyperpycnal } \\
\text { lobe fringe } \\
\text { (sand-rich) }\end{array}$ & $10-50 \mathrm{~cm}$ & $\begin{array}{l}\text { Tabular to } \\
\text { lenticular } \\
\text { beds }\end{array}$ & $\begin{array}{l}\text { Fine to very fine-grained } \\
\text { sandstone }\end{array}$ & $\begin{array}{l}\text { Structureless, some } \\
\text { wave ripples, } \\
\text { combined-flow } \\
\text { ripples, parallel } \\
\text { lamination, and } \\
\text { minor current } \\
\text { ripples }\end{array}$ & Unbioturbated & Plant debris & $\begin{array}{l}\text { Hyperpycnal } \\
\text { flows reworked } \\
\text { by } \\
\text { combined-flows }\end{array}$ & $\begin{array}{l}\text { Encased in F6b, } \\
\text { located in } \\
\text { bottomset areas }\end{array}$ \\
\hline $\begin{array}{l}\text { F6b: Hyperpycnal } \\
\text { lobe fringe } \\
\text { (mud-rich) }\end{array}$ & $1-10 \mathrm{~cm}$ & Tabular & $\begin{array}{l}\text { Heterolithic successions of } \\
\text { argillaceous coarse to fine } \\
\text { mudstone, minor very } \\
\text { fine-grained sandstone }\end{array}$ & $\begin{array}{l}\text { Structureless, minor } \\
\text { ripple } \\
\text { cross-lamination }\end{array}$ & Unbioturbated & Plant debris & $\begin{array}{l}\text { Muddy } \\
\text { hyperpycnal } \\
\text { flow and lofting } \\
\text { processes }\end{array}$ & $\begin{array}{l}\text { Vertically and } \\
\text { laterally } \\
\text { associated with } \\
\text { F6a and F7 }\end{array}$ \\
\hline $\begin{array}{l}\text { F7: Hyperpycnal } \\
\text { lobe }\end{array}$ & $5-50 \mathrm{~cm}$ & $\begin{array}{l}\text { Tabular } \\
\text { beds }\end{array}$ & $\begin{array}{l}\text { Medium to fine-grained } \\
\text { sandstone }\end{array}$ & $\begin{array}{l}\text { Structureless, } \\
\text { parallel lamination, } \\
\text { combined-flow } \\
\text { ripples, and HCS. } \\
\text { Water escape } \\
\text { structures occur }\end{array}$ & Unbioturbated & Plant debris & $\begin{array}{l}\text { Hyperpycnal } \\
\text { flows reworked } \\
\text { by combined } \\
\text { flows }\end{array}$ & $\begin{array}{l}\text { Occur in } \\
\text { bottomset areas, } \\
\text { intercalated } \\
\text { with minor } \\
\text { facies F6a or F6b }\end{array}$ \\
\hline $\begin{array}{l}\text { F8a: Channel-fill } \\
\text { complex }\end{array}$ & $0.1-3 \mathrm{~m}$ & $\begin{array}{l}\text { Tabular to } \\
\text { lenticular } \\
\text { bodies with } \\
\text { lateral } \\
\text { accretion }\end{array}$ & $\begin{array}{l}\text { Medium-grained } \\
\text { sandstone }\end{array}$ & $\begin{array}{l}\text { Structureless, } \\
\text { parallel-bedding, } \\
\text { trough } \\
\text { cross-bedding, HCS, } \\
\text { combined-flow } \\
\text { ripples, and minor } \\
\text { current and } \\
\text { climbing ripples and } \\
\text { sigmoidal } \\
\text { cross-stratification }\end{array}$ & Unbioturbated & $\begin{array}{l}\text { Bivalve } \\
\text { bioclasts }\end{array}$ & $\begin{array}{l}\text { High-energy } \\
\text { bedload } \\
\text { sedimentation } \\
\text { in a } \\
\text { meandering, } \\
\text { subaqueous } \\
\text { sandy channel }\end{array}$ & $\begin{array}{l}\text { Occurs in } \\
\text { bottomset to } \\
\text { foreset areas, in } \\
\text { a landward } \\
\text { position }\end{array}$ \\
\hline
\end{tabular}


Table 1 (continued)

\begin{tabular}{|c|c|c|c|c|c|c|c|c|}
\hline Facies & $\begin{array}{l}\text { Bedding } \\
\text { thickness }\end{array}$ & Geometry & Lithology & $\begin{array}{l}\text { Sedimentary } \\
\text { structures }\end{array}$ & Ichnology & $\begin{array}{l}\text { Fossil } \\
\text { content }\end{array}$ & Interpretation & $\begin{array}{l}\text { Distribution in } \\
\text { the section }\end{array}$ \\
\hline F8b: Overbank & $\begin{array}{l}5-30 \mathrm{~cm} \text { in } \\
\text { the } \\
\text { sandstone } \\
\text { and } 0.5-1 \\
\mathrm{~cm} \text { in the } \\
\text { heterolithics }\end{array}$ & Tabular & $\begin{array}{l}\text { Fine-grained sandstone } \\
\text { and mud-rich heterolithic } \\
\text { successions of very } \\
\text { fine-grained sandstone and } \\
\text { argillaceous fine mudstone }\end{array}$ & $\begin{array}{l}\text { Massive and ripple } \\
\text { cross-lamination }\end{array}$ & Unbioturbated & - & $\begin{array}{l}\text { Crevasse splay } \\
\text { deposition and } \\
\text { suspension } \\
\text { fallout } \\
\text { sedimentation } \\
\text { from lofting } \\
\text { clouds }\end{array}$ & $\begin{array}{l}\text { Occurs in } \\
\text { bottomset to } \\
\text { foreset areas, in } \\
\text { a landward } \\
\text { position }\end{array}$ \\
\hline F9a: Slope mud belt & $5-10 \mathrm{~cm}$ & Tabular & $\begin{array}{l}\text { Argillaceous fine } \\
\text { mudstone, minor very } \\
\text { fine-grained sandstone }\end{array}$ & $\begin{array}{l}\text { Silt laminae, slumps, } \\
\text { sand dykes and } \\
\text { syn-sedimentary } \\
\text { faults }\end{array}$ & Unbioturbated & $\begin{array}{l}\text { Bivalve and } \\
\text { ammonite } \\
\text { shells }\end{array}$ & $\begin{array}{l}\text { Higher } \\
\text { siliciclastic } \\
\text { input by mud } \\
\text { redistribution } \\
\text { processes and } \\
\text { mass } \\
\text { movements }\end{array}$ & $\begin{array}{l}\text { Lower and } \\
\text { middle foreset } \\
\text { areas }\end{array}$ \\
\hline F9b: Mixed slope & $1-10 \mathrm{~cm}$ & Tabular & $\begin{array}{l}\text { Intraclastic wackestone, } \\
\text { minor calcareous } \\
\text { fine-grained sandstone }\end{array}$ & Structureless & $\begin{array}{l}\text { Bioturbate } \\
\text { mottlings }\end{array}$ & $\begin{array}{l}\text { Bivalve and } \\
\text { ammonite } \\
\text { shells }\end{array}$ & $\begin{array}{l}\text { Mixed } \\
\text { sedimentation } \\
\text { in an oxic } \\
\text { environment }\end{array}$ & $\begin{array}{l}\text { Upper foreset } \\
\text { areas }\end{array}$ \\
\hline $\begin{array}{l}\text { F10: Slope sand } \\
\text { bodies }\end{array}$ & $0.1-3 \mathrm{~m}$ & $\begin{array}{l}\text { Lenticular } \\
\text { to tabular }\end{array}$ & $\begin{array}{l}\text { Calcareous fine-grained } \\
\text { sandstone and minor } \\
\text { intraclastic wackestone }\end{array}$ & $\begin{array}{l}\text { Structureless, } \\
\text { locally parallel } \\
\text { lamination and } \\
\text { low-angle cross } \\
\text { stratification }\end{array}$ & Unbioturbated & $\begin{array}{l}\text { Bivalve } \\
\text { shells }\end{array}$ & Spillover lobes & Foreset areas \\
\hline F11a: Sandy shoal & $\begin{array}{l}1-3 \mathrm{~m} \text { in the } \\
\text { sandstone } \\
\text { and } 0.1-1 \mathrm{~m} \\
\text { in the } \\
\text { wackestone } \\
\text { and } \\
\text { packstone }\end{array}$ & Tabular & $\begin{array}{l}\text { Calcareous sandstone, } \\
\text { wackestone and packstone }\end{array}$ & $\begin{array}{l}\text { Structureless, minor } \\
\text { low-angle } \\
\text { cross-bedding and } \\
\text { wave ripples }\end{array}$ & $\begin{array}{l}\text { Bioturbate } \\
\text { mottlings, some } \\
\text { Thalassinoides isp. } \\
\text { and Palaeophycus } \\
\text { tubularis }\end{array}$ & $\begin{array}{l}\text { Bivalve and } \\
\text { ammonite } \\
\text { shells }\end{array}$ & $\begin{array}{l}\text { Wave } \\
\text { reworking and } \\
\text { sand shoal } \\
\text { progradation in } \\
\text { an oxic } \\
\text { environment }\end{array}$ & $\begin{array}{l}\text { Foreset to topset } \\
\text { transition }\end{array}$ \\
\hline $\begin{array}{l}\text { F11b: Sand bar } \\
\text { complex }\end{array}$ & $1-5 \mathrm{~m}$ & $\begin{array}{l}\text { Tabular to } \\
\text { large-scale } \\
\text { lenticular }\end{array}$ & $\begin{array}{l}\text { Rudstone, floatstone and } \\
\text { calcareous coarse- to } \\
\text { medium-grained } \\
\text { sandstone }\end{array}$ & $\begin{array}{l}\text { Planar to trough } \\
\text { cross-stratification, } \\
\text { minor ripple } \\
\text { cross-lamination }\end{array}$ & Escape traces & $\begin{array}{l}\text { Bivalve, } \\
\text { gastropod } \\
\text { and } \\
\text { ammonite } \\
\text { shells }\end{array}$ & $\begin{array}{l}\text { Subaqueous } \\
\text { dune migration } \\
\text { in a high energy } \\
\text { environment }\end{array}$ & $\begin{array}{l}\text { Top of the } \\
\text { sections }\end{array}$ \\
\hline F12: Lagoon & mm-thick & Tabular & $\begin{array}{l}\text { Medium-grained } \\
\text { sandstone }\end{array}$ & $\begin{array}{l}\text { Structureless to } \\
\text { parallel-lamination }\end{array}$ & Unbioturbated & $\begin{array}{l}\text { Bivalve } \\
\text { bioclasts }\end{array}$ & $\begin{array}{l}\text { Protected, } \\
\text { stressed } \\
\text { environment }\end{array}$ & $\begin{array}{l}\text { Topset to foreset } \\
\text { transition }\end{array}$ \\
\hline
\end{tabular}

successions occur. Wackestone and packstone are composed of wellpreserved to partially fragmented, bivalve, ammonite, and gastropod shells. Poorly defined biodeformational structures are crosscut by Thalassinoides isp. showing sharp, unlined walls (Fig. 6d). Thalassinoides is passively infilled by medium- to coarse-grained sandstone. Bioturbation intensity is extremely variable (BI-1-6). F3 shows a high lateral variation of thickness (1-2 m), and overlies the Quebrada del Sapo Formation where F2 and F1 are absent.

F3 represents sedimentation in an open bay margin environment, above fair-weather wave base. Symmetrical ripples and bioclastic wackestone and packstone suggest wave reworking and sediment bypass associated with transgressive condensation. The Thalassinoides isp. suite crosscutting the biodeformational structures was emplaced under firmground conditions evidenced by the sharp, unlined walls and passive infill. The coarse-grained sandstone infilling burrows was probably bypassed from this area of high-energy to the distal bay area (F4), where sandstone beds are preserved.

\subsubsection{Facies 4 (F4)}

This facies consists in carbonaceous medium mudstone showing minor, 5-20 cm-thick, sharp- to erosive-based, grayish-green mudstone, medium-grained sandstone and tuff beds. TOC content is moderate (mean $=2.37 \%, N=2$ ). The background carbonaceous mudstone displays abundant $0.2-1 \mathrm{~mm}$-long, oval to round-shaped pellets in the matrix, whereas the grayish-green mudstone shows pellets at the base. The sandstone shows normal gradation with organic-rich intraclasts located at the base. Ammonite, bivalve and gastropods shells are minor components of the mudstone. This facies is moderately bioturbated (BI 2-3), displaying biodeformational structures. Discrete trace fossils, such as Thalassinoides isp., Palaeophycus tubularis and Teichichnus rectus, can be observed when sediment contrast provided by a change in mudstone color, sandstone or tuff intervals occur (Fig. 6c, e). This facies also has variable thickness (2-10 m).

This facies records deposition in a distal bay environment with medium mudstone deposits indicative of low-energy, hemipelagic sedimentation. Deposition below the fair-weather wave base promoted preservation of sandstone and grayish mudstone beds probably representing sandy concentrated density flows (e.g. Eschner and Kocurek, 1986) and muddy tempestites bypassed from the higher energy coast, respectively. The trace fossil content shows the establishment of suspension feeders and passive predators with minor deposit feeders (Buatois and Mángano, 2011).

\subsubsection{FAA interpretation}

The absence of proximal, storm-generated shoreface deposits indicates a low-energy, retrograding coast developing an open bay succession (MacEachern and Gingras (2007). An absence of bay mouth facies suggests the deposits can be assigned to an open bay rather than to a restricted bay (MacEachern and Gingras, 2007).

\subsection{Facies assemblage $B(F A B)$}

\subsubsection{Facies 5 ( F5)}

F5 is composed by thick-bedded $(1 \mathrm{~m})$ cycles grading from parallel-laminated carbonaceous-argillaceous fine mudstone (Fmud) to argillaceous medium mudstone (Mmud, Fig. 7a). Rare 
Facies
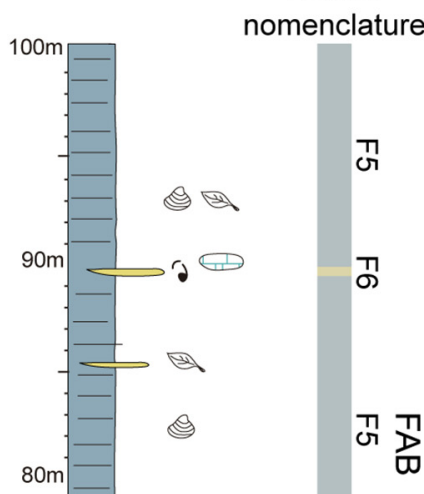

진

뀨

筧

꽁

뀽

강

꾱

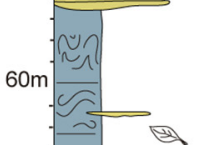

$=$ -

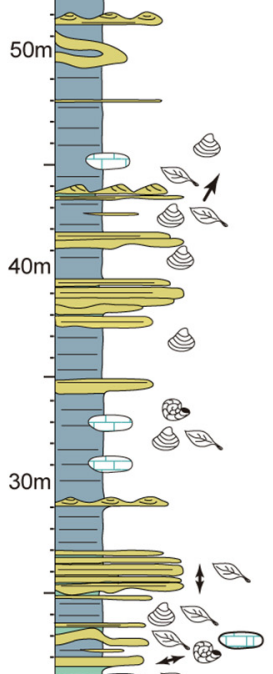

$20 \mathrm{~m}$ 要

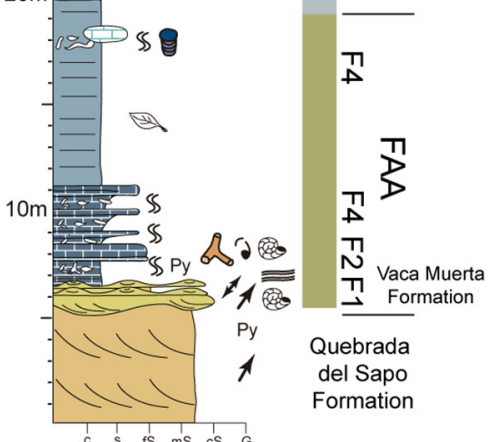

죵

꿍

꼬

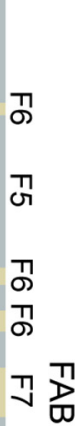

꾜

간

꾱

ग

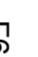

గু

낑

חె

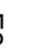

(2)

Facies nomenclature

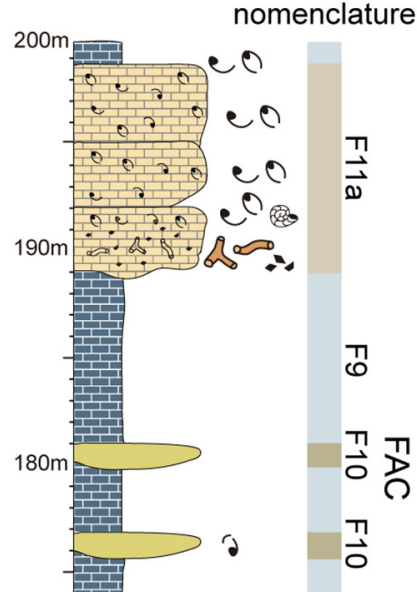

ᄁᄁ

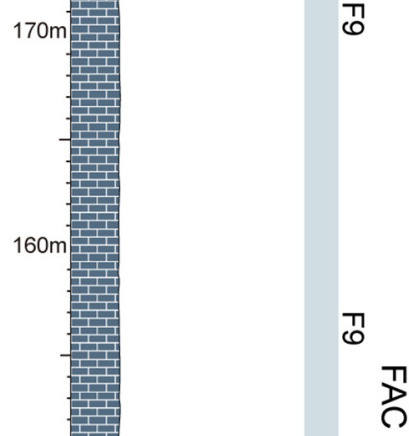



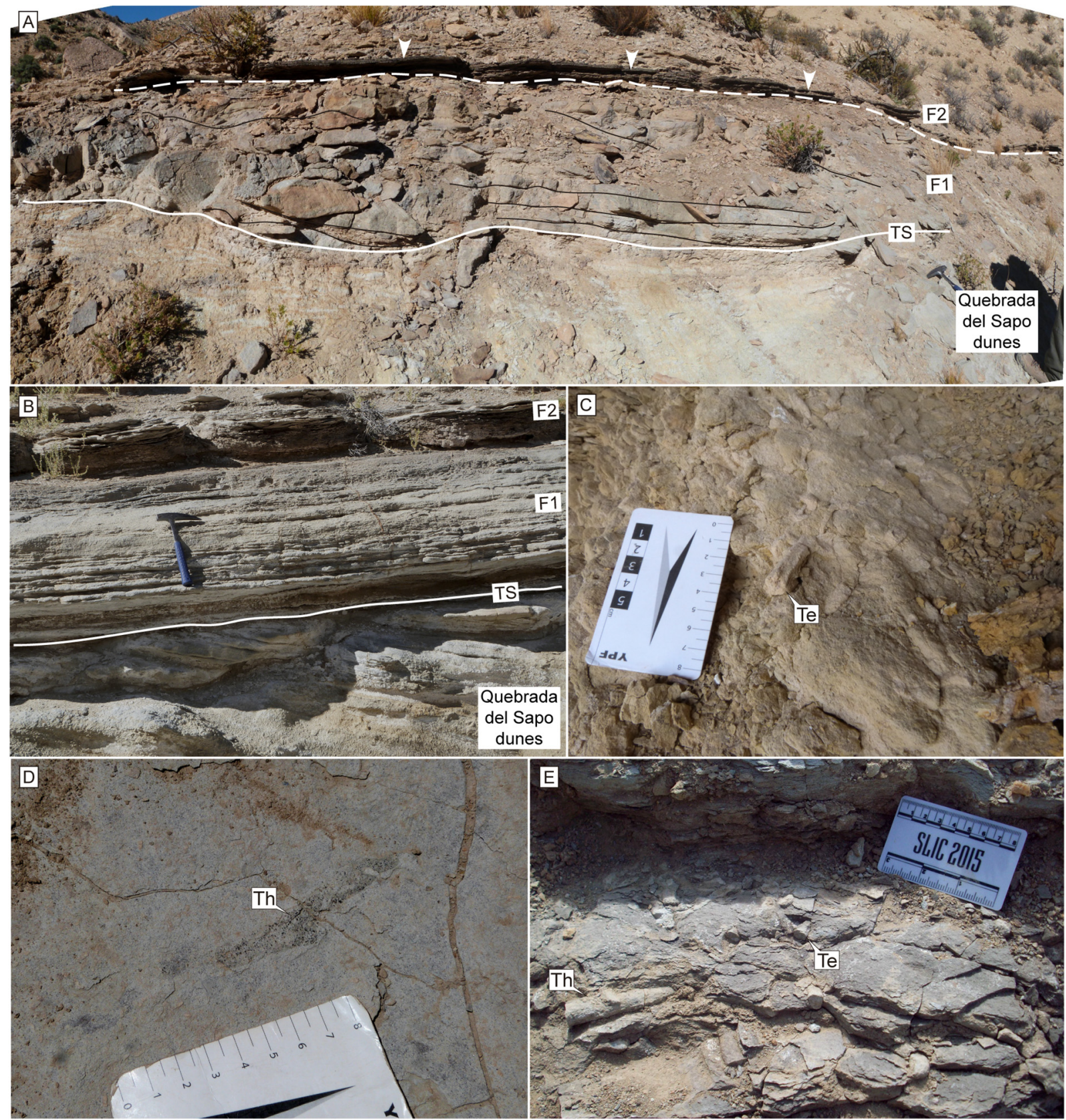

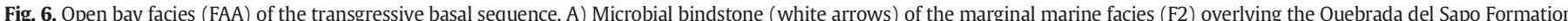

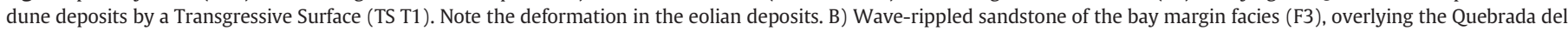

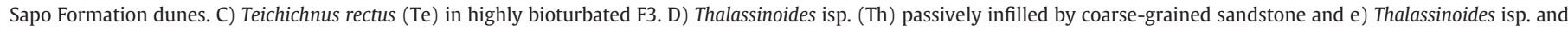
Teichichnus rectus of the second trace fossil association, in distal bay facies (F4).

isolated, very thin $(0.5-2 \mathrm{~cm})$ massive fine mudstone beds also occur (Fig. 7b). The parallel-laminated mudstone shows a discontinuous, anastomosing, wrinkle lamination produced by kerogen seams (Fig. 7c). TOC content in the parallel-laminated mudstone is high $(0.03-12.20 \%$, mean $=3.24 \%, N=31)$, compared with the massive fine mudstone (1.18\% of TOC). Soft-sediment deformation structures include slumps, sand dykes and syn-sedimentary faults. Oblateshaped, 20 to $70 \mathrm{~cm}$ long carbonate concretions are observed in the lower and middle part of the sections. The fossil content mainly consists of high- to moderate-density accumulations of flattened bivalve shells occurring on bedding planes. Pectinid bivalves (Huncalotis; $\mathrm{H}$. Leanza, written communication) are found as shell pavements and include both a widespread small-sized ( $2-5 \mathrm{~mm}$ long) population and a more localized one of larger (1-2 cm long) bivalves. Ammonites, plant debris and fish scales are minor constituents. Ammonites are well-preserved to fragmented, with specimens up to $20 \mathrm{~cm}$ wide. Trace fossils are absent.

High amounts of organic matter and a relative absence of event, discrete beds suggest deposition in a sediment-starved basinal environment. Hemipelagic deposition dominated this area, with the organic matter provided by marine snow and silt derived by eolian input (Gabbott et al., 2010). Occasionally, massive fine mudstone could represent buoyant plumes advected from the slope area, diluting organic matter content (e.g. Wright and Nittrouer, 1995). As the study area is located at a tectonically active zone at the time of deposition, soft-sediment deformation structures were probably triggered by seismicity, at the base of the 
slope. In thin section, the wrinkled lamination and bed contacts observed are not crosscut or disrupted by bioturbation structures, suggesting oxygen deficiency at bottom and interstitial waters. Bivalve shell pavements are abundant in some black shale successions, such as the Posidonia Shale of Germany, and may reflect short-term benthic colonization due to fluctuating oxygen conditions (Röhl et al., 2001).

\subsubsection{Facies 6 (F6)}

This facies is composed by sharp- to erosive-based, medium-bedded $(10-50 \mathrm{~cm}$ ), fine- to very fine-grained sandstone (F6a, Fig. 8), and mudrich heterolithic successions of thin-bedded $(1-10 \mathrm{~cm})$, massive, argillaceous coarse to fine mudstone (F6b, Fig. 9a). TOC content in the mudstone is low $(0.18-0.99 \%$, mean $=0.48 \%, N=5)$. Although the sandstone is mostly massive, some sedimentary structures, including wave ripples (Fig. 8b, c), combined-flow ripples, parallel lamination, and minor current ripples, occur. Grooves are common at the base of the sandstone and within amalgamated sandstone delineating erosive surfaces. Paleocurrents from current ripples and grooves have two mean vectors, NNE-SSW and E W $(n=8)$. The sandstone contains chaotically distributed, $1-3 \mathrm{~mm}$ long plant debris (1-2\%, Fig. 8d) or concentrated together with minor rip-up mudstone clasts in discrete beds at the base (20-30\%). The coarse mudstone shows abundant, up to $2 \mathrm{~cm}$ long plant debris (30-50\%), micas (5\%), and deformed rip-up fine mudstone intraclasts $(0-10 \%$, Fig. 9b), whereas the fine mudstone contains smaller (1 to $0.5 \mathrm{~mm}$ long) plant remains (5-10\%, Fig. 9c), which can show a plant-debris normal grading from base to top. This facies occurs as alternations of tabular or lenticular beds showing F6a encased in F6b (Fig. 8a).

This facies is associated with sandy and muddy hyperpycnal flow sedimentation in a lobe fringe, basinal setting. Wave ripples and combined-flow ripples indicate oscillatory and combined wave oscillatory and unidirectional geostrophic flow reworking due to storm influence (Plint, 2010). Paleocurrent trends of current ripples (NNE) and groove casts (ENE-WSW) show a vector of transport parallel to the direction of clinothem progradation (NE). Plant debris in the sandstone and mudstone indicates an extrabasinal origin for these flows (Mulder and Chapron, 2011; Ponce and Carmona, 2011a,b; Zavala et al., 2012), supporting a hyperpycnal flow origin. The sedimentary structures can be compared with the genetic facies model of hyperpycnal flows put forward by Zavala et al. (2011). Therefore, the massive fine-grained sandstone was formed by progressive aggradation from highsuspended load long-lived currents, whereas the minor parallellaminated and ripple cross-laminated sandstone indicates traction processes. The coarse mudstone was produced by turbidity currents that reworked plant debris and unconsolidated fine mud from an early phase of deposition (Zavala and Arcuri, 2016). In addition, lofting occurs by negative buoyancy reversal of a hyperpycnal flow as a result of flow deceleration (Sparks et al., 1993), generating the fine mud and sorting process of the smaller plant debris. Encasement of F6a within mudrich F6b indicates a waxing to waning current showing its higher energy peak in the sandy F6a deposits.

\subsubsection{Facies 7 (F7)}

This facies comprises sharp- to erosive-based, medium- to thinbedded $(5-50 \mathrm{~cm})$, medium- to fine-grained sandstone (Fig. 10a). The sandstone contains, in order of abundance, massive beds, parallel lamination, combined-flow ripples, and hummocky cross-stratification (HCS). Water escape structures also occur. Load casts and grooves are preserved at the base of the sandstone. Grooves exhibit paleocurrents trending N-S and ENE-WSW $(n=2)$. The sandstone contains isolated and randomly distributed, $1-5 \mathrm{~mm}$ long plant debris, up to $10 \mathrm{~cm}$ wide rip-up mudstone clasts, and minor bivalve shell fragments. Discrete, high-concentrated layers of plant debris (30-40\%) and mudstone clasts (30-40\%) are also common (Fig. 10b, c), with plant debris delineating sandstone parallel lamination in some cases. This facies commonly occur grouped in bedsets, developing coarsening- and thickening-upward patterns at the base, and fining- and thinningupward patterns at the top. Beds are tabular, with some swale and hummock geometries on the top. Intra-bed erosive surfaces delineated by mudstone clast breccias are also common. This facies is locally intercalated with thin intervals of facies 6

This facies represents hyperpycnal flow sedimentation affected by combined-flow action (as indicated by combined-flow ripples and HCS) in a lobe setting. Deposition of massive and parallel-laminated, plant debris-rich sandstone reflects the transition from relatively high to lower fallout rates that promoted plant debris trapping in the sandstone (Zavala et al., 2012). The mudstone-clast breccia indicates erosion

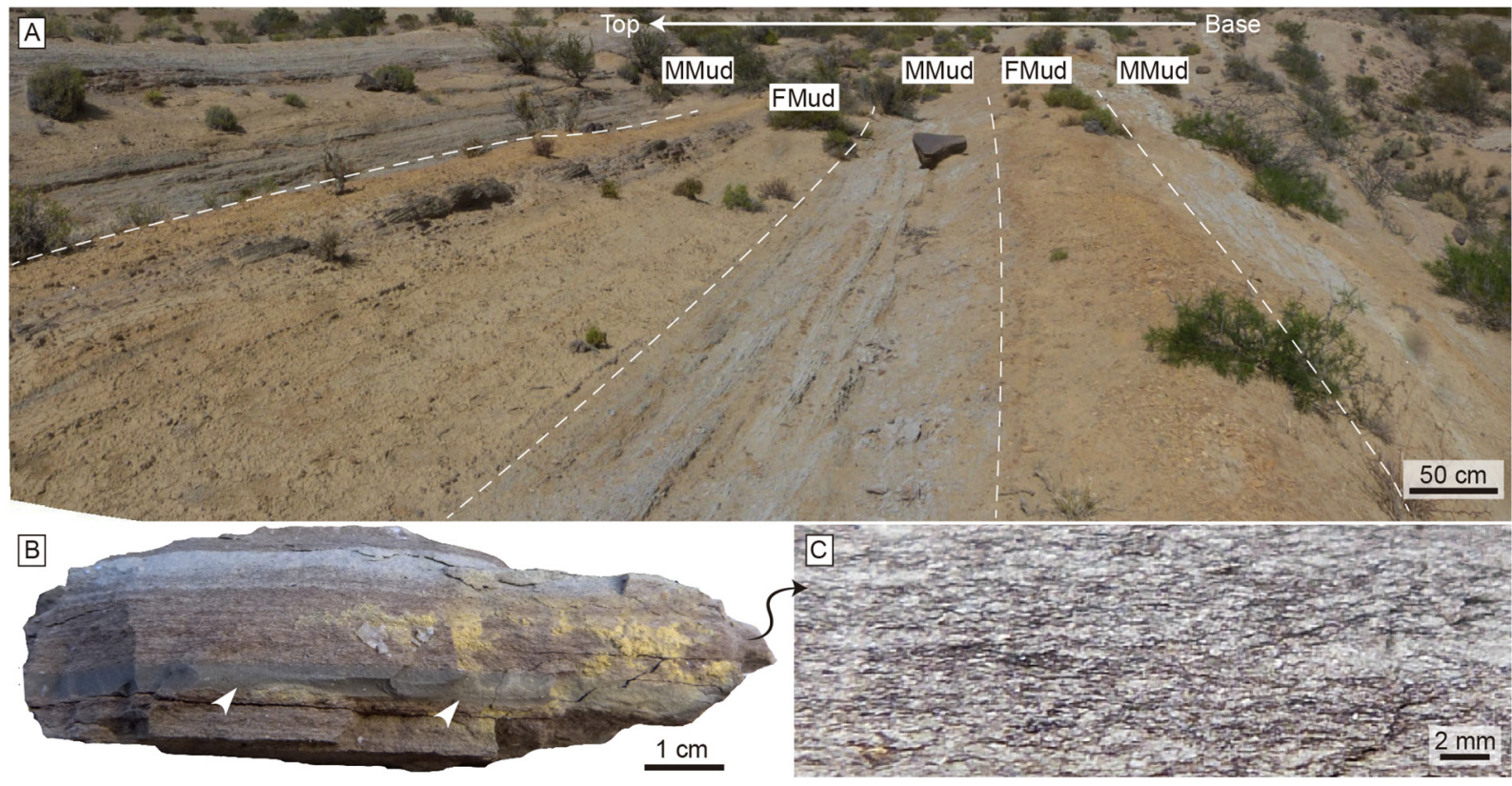

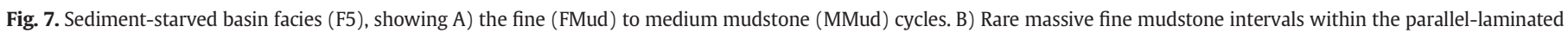
mudstone. C) Close-up photograph of parallel-laminated mudstone displaying the kerogen seams (darker wrinkled laminae) 
and bedload deposition. Evidence of alternation between massive and parallel-laminated facies in the same interval and intra-bed erosive surfaces indicate fluctuations in the flow regime. Deposition from more concentrated density currents in comparison with the lobe fringe facies (F6) is indicated by the coarser grains, common occurrence of rip-up mudstone clasts, thicker sandstone lithofacies, and relative lack of lobe fringe muddy deposits (F6b). The thickening at the base and thinning at the top patterns of the bedsets can be explained by the shifting of the lobe depocenter at different scales (Prélat and Hodgson, 2013), generating intercalation of lobe and lobe fringe deposits.

\subsubsection{Facies 8 (F8)}

This facies is composed by erosive-based, medium- to thick-bedded (0.1-3 m), medium-grained sandstone (F8a, Fig. 11a) and by thin- to medium-bedded $(5-30 \mathrm{~cm})$, fine-grained sandstone and mud-rich heterolithic successions of very thin-bedded $(0.5-1 \mathrm{~cm})$, very finegrained sandstone and argillaceous fine mudstone (F8b, Fig. 12b). Although massive beds are distinctive, sedimentary structures in the sandstone include parallel-bedding, trough cross-bedding (Fig. 11b) and HCS, combined-flow ripples, and minor current and climbing ripples and sigmoidal cross-stratification. The sandstone in the heterolithic succession shows ripple cross-lamination, with organic matter in the lamination (Fig. 12c). Large-scale water escape structures (Fig. 11a, c) and slumps are common in the otherwise massive beds. Bioclast and rip-up mudstone clasts occur at the base of the sandstone, forming mudstone-clast breccia that delineates bed contacts or isolated in the sandstone. The mudstone shows mm-thick medium- to fine-grained sand and organic matter lags. At an outcrop scale, F8a constitute tabular or lenticular bodies, the latter exhibiting lateral accretion (Fig. 12a). Minor gutter cast geometries also occur. These bodies are stacked
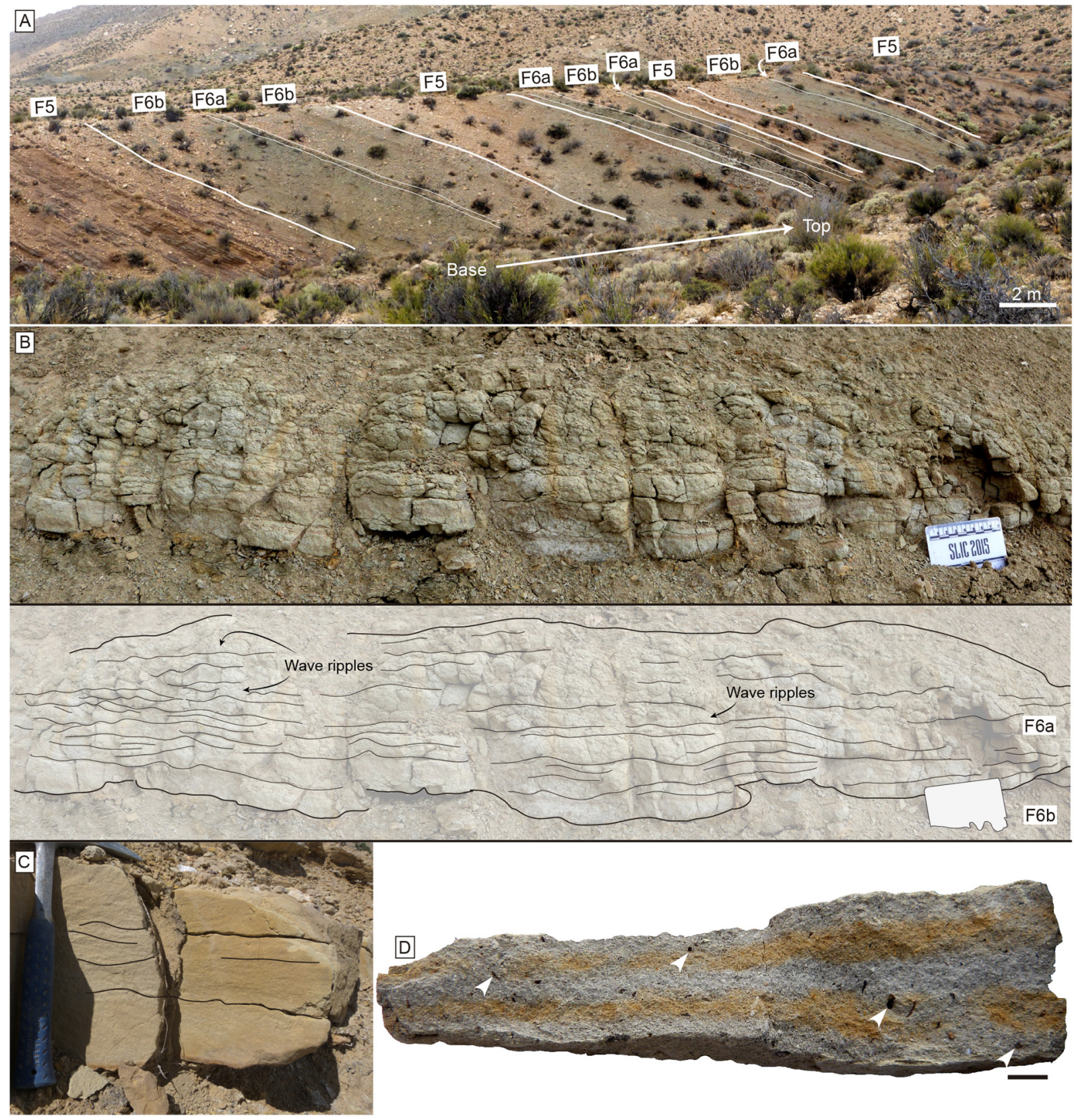

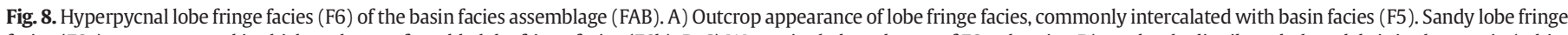

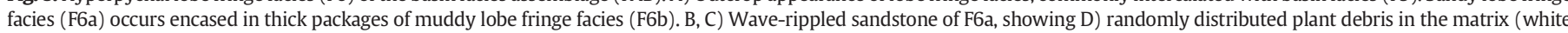
arrows, scale bar is $1 \mathrm{~cm}$. 

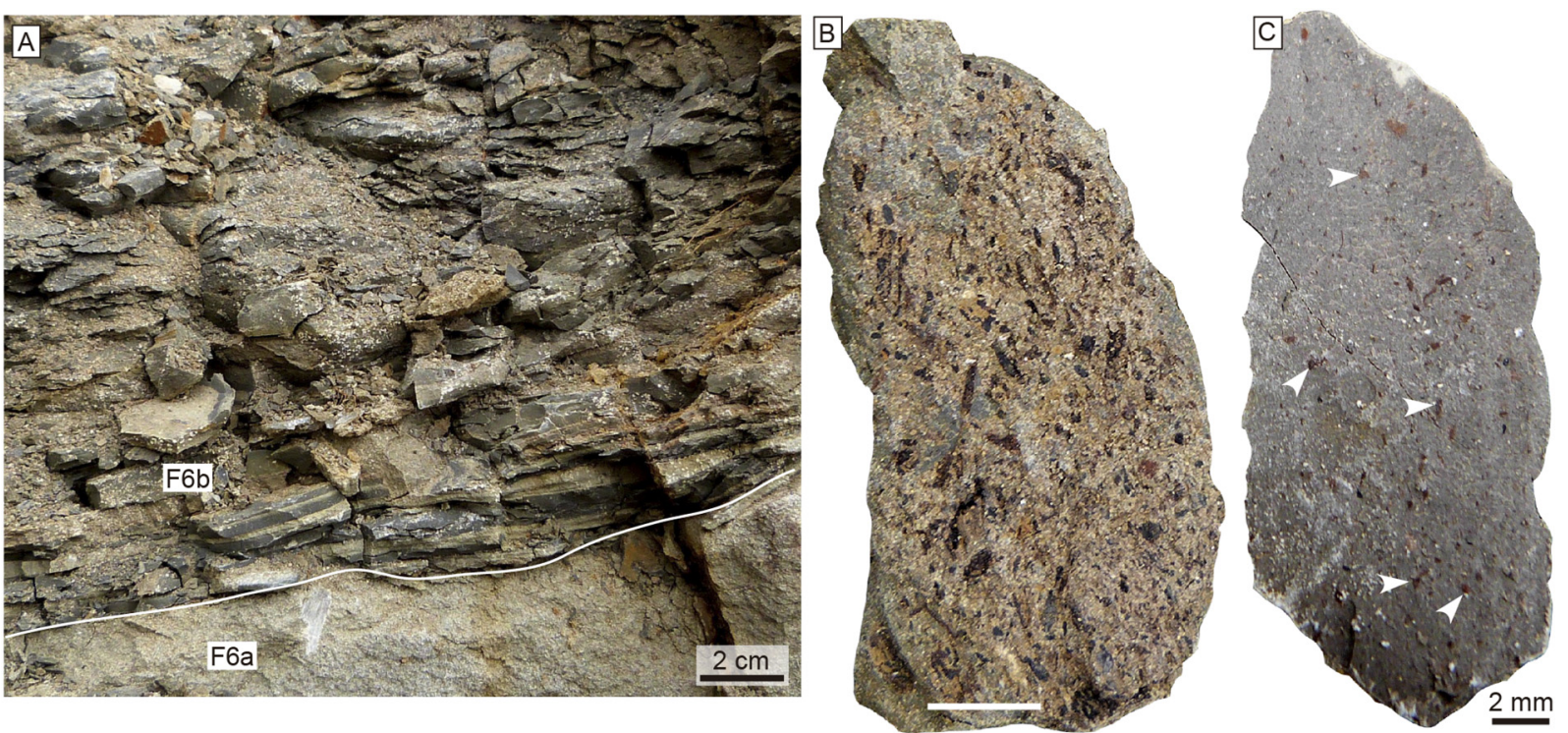

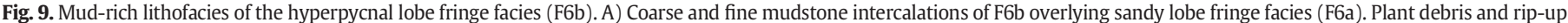
mudstone clasts occur in the coarse mudstone (F, scale bar is $1 \mathrm{~cm}$ ), whereas fine mudstone contains smaller plant material ( $\mathrm{G}$, white arrows).

forming 50 to $100 \mathrm{~m}$ wide and up to $12 \mathrm{~m}$ thick units. F8b is laterally and vertically associated with facies 8 a.

This facies is interpreted as a meandering channel-fill complex (F8a) and overbank (F8b) subject to hyperpycnal flow sedimentation. Multiple erosive reactivation surfaces and rip-up mudstone clasts indicate high-energy bedload sedimentation and erosion in or at the channel base (Zavala et al., 2011). Deposition from dense cohesion-less suspension can generate liquefied flows with water escape structures (Mulder and Alexander, 2001). High amounts of massive beds and large-scale water escape structures indicate rapid deposition due to loss of flow capacity in a slope break location. HCS, combined-flow ripple, and gutter cast occurrence point towards a storm-influenced setting. Bypassing of the low-density turbidity cloud and/or erosion by the successive hyperpycnal flows prevented fine-grained sediment and plant debris accumulation. The fine-grained sandstone of F8b represents crevasse splays, whereas the heterolithic succession shows the combination of unidirectional traction structures in very fine-grained sandstone produced by turbidity currents that overtop the channel margins, and

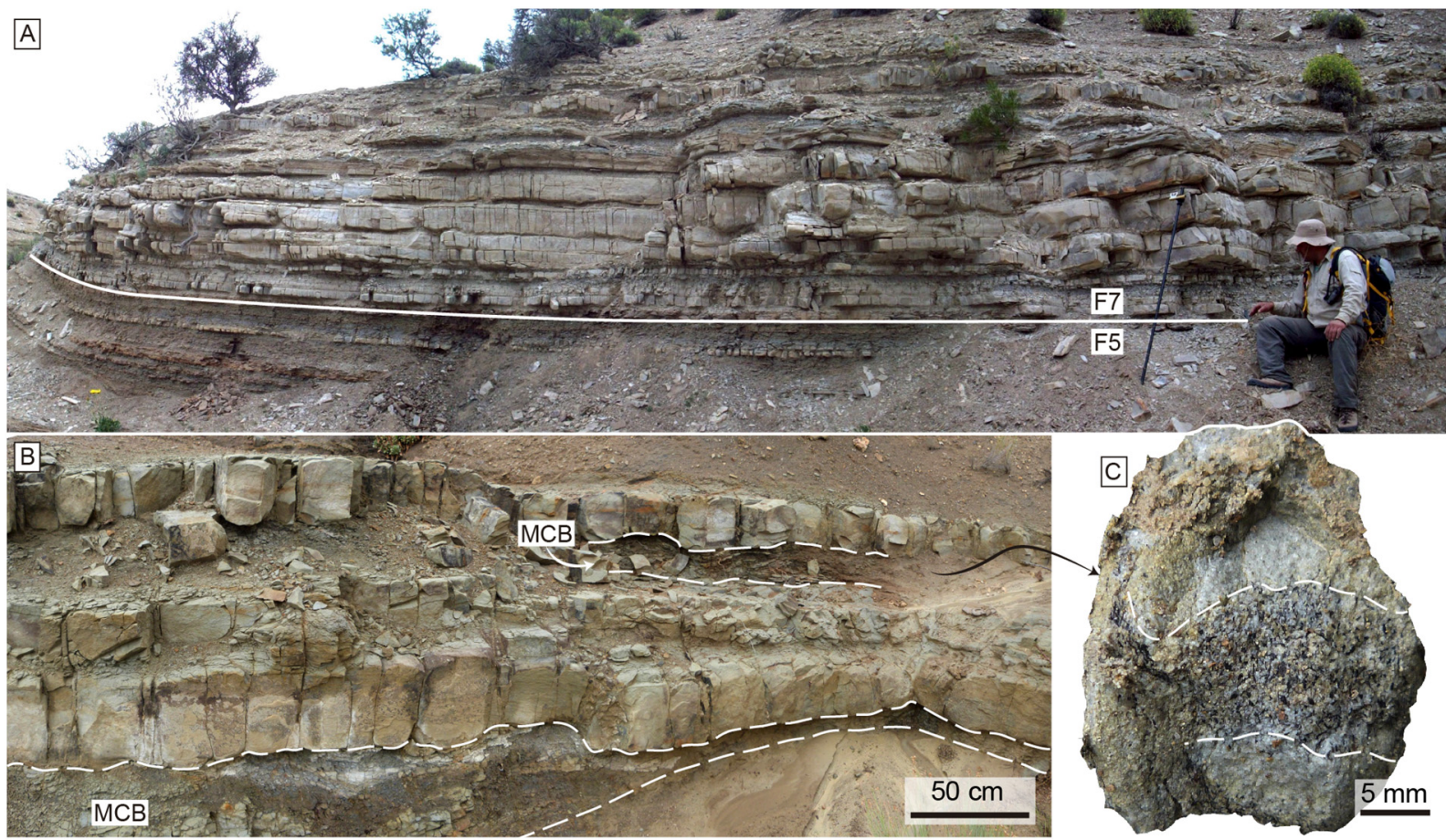

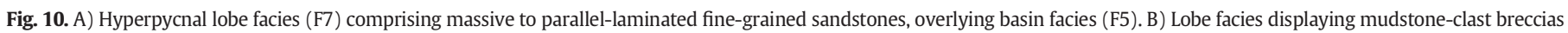
(MCB) at the sandstone bases. C) Close-up view of high-concentrated plant debris layers that delineates lamination. 

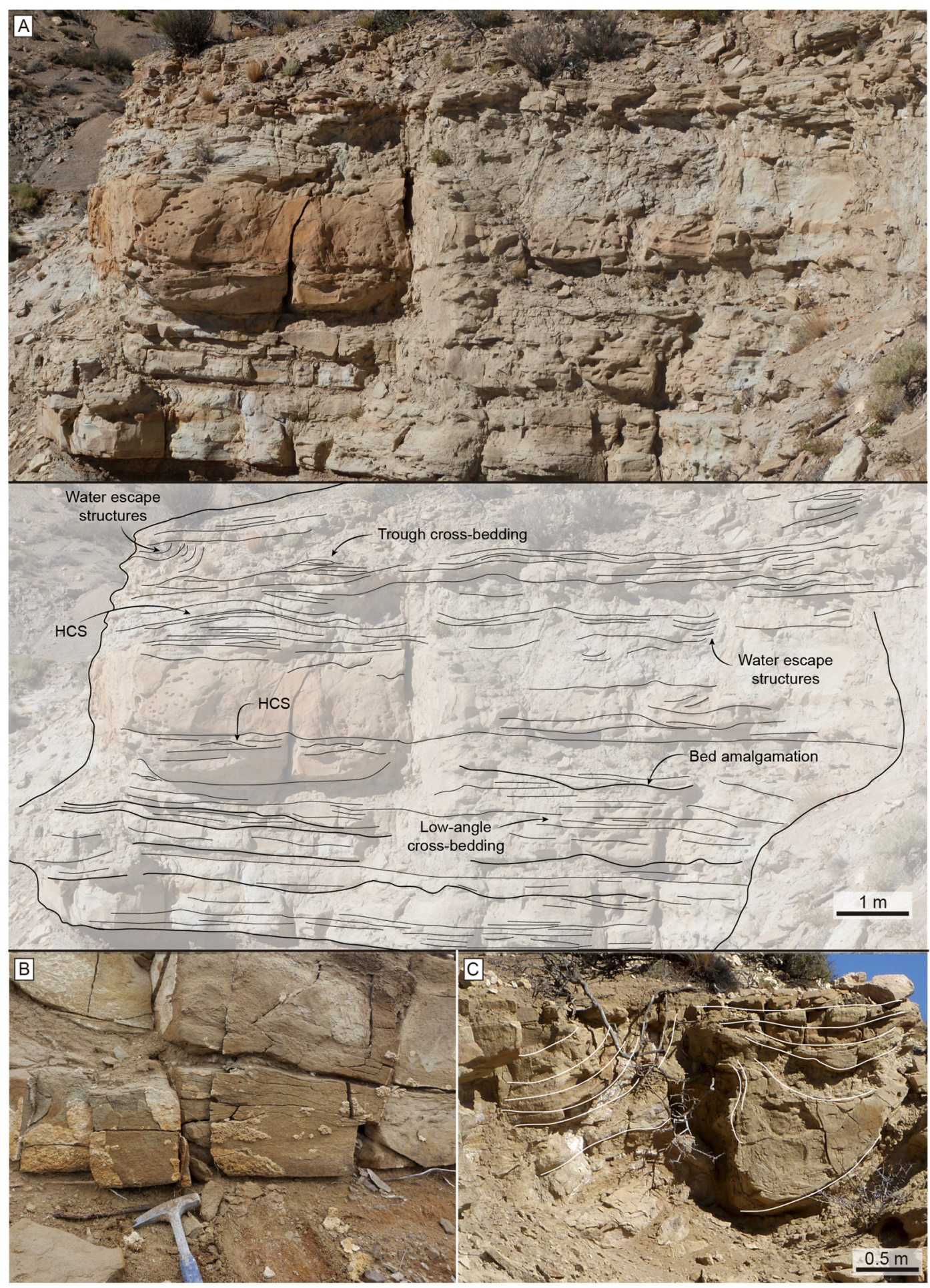

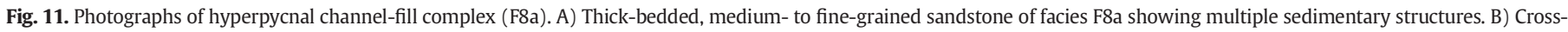
stratification and C) high-scale water escape structures in facies F8a.

mudstone lithofacies interpreted as suspension fallout from lofting clouds developed adjacent to the channel. The sand and organic matter lags probably indicate the resuming of hemipelagic conditions characteristic of the basin facies (F5).

\subsubsection{FAB interpretation}

This facies assemblage is characterized by bottomset geometries (Fig. 13) and alternation of hyperpycnal deposits and sedimentstarved, hemipelagic conditions, suggesting a siliciclastic basin environment associated with a mixed shelf (see below). The hyperpycnal system is described with the turbidity element nomenclature utilized by Mutti and Normark (1991).

\subsection{Facies assemblage $C(F A C)$}

\subsubsection{Facies 9 (F9)}

This facies consists of parallel-laminated, grey, argillaceous fine mudstone, with minor thin-bedded $(5-10 \mathrm{~cm})$ very fine-grained 


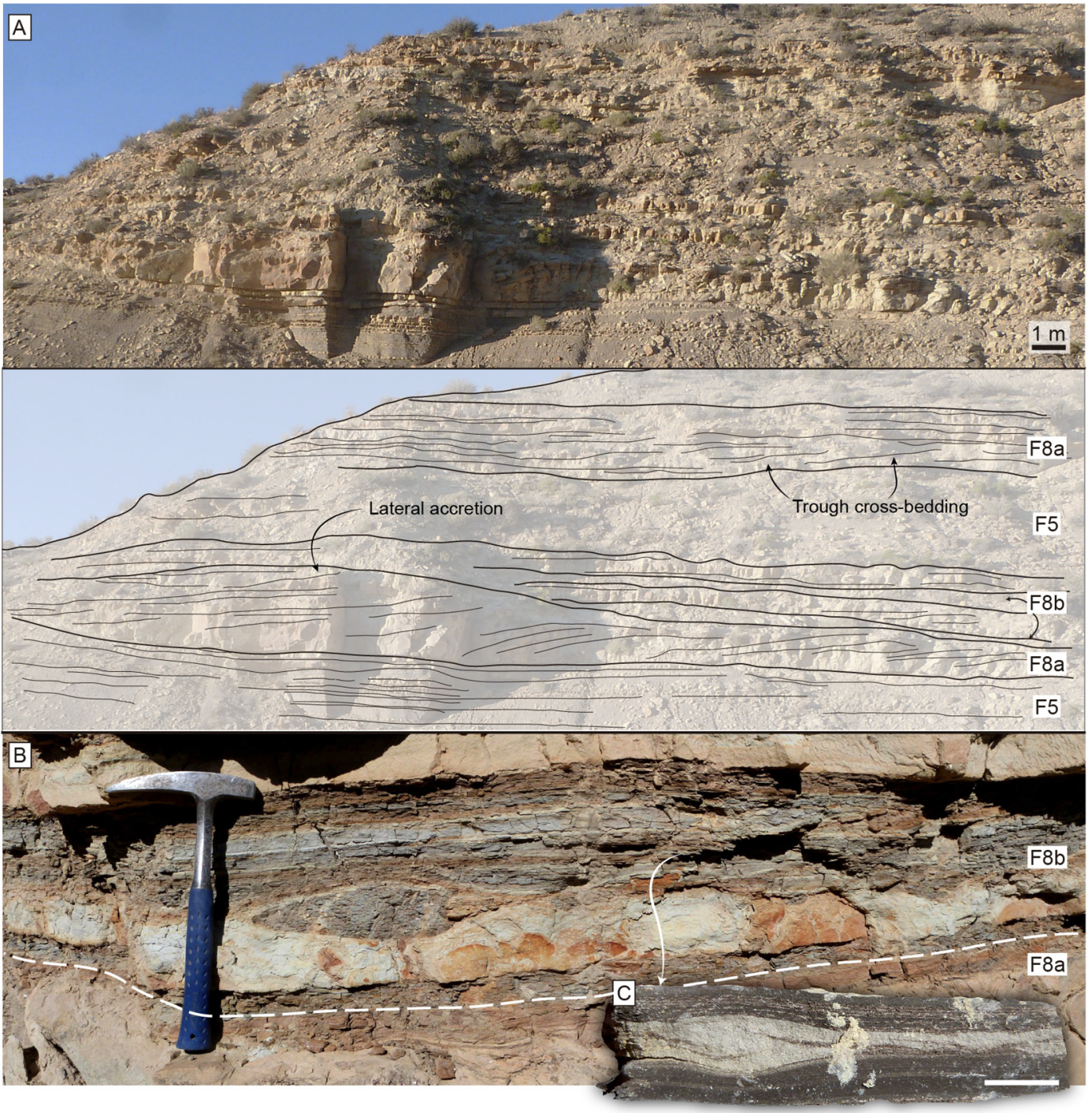

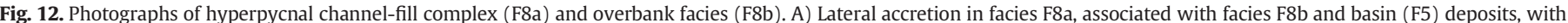

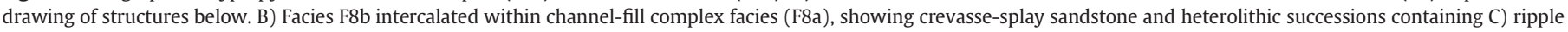
cross-laminated sandstone (scale is $1 \mathrm{~cm}$ ).

sandstone (F9a, Fig. 14a, b) and coarsening upwards successions of thinbedded $(1-10 \mathrm{~cm})$, massive to mottled, green, dolomitic intraclastic wackestone capped by medium-bedded $(10-50 \mathrm{~cm})$, calcareous finegrained sandstone beds (F9b, Fig. 14a, c). Laminae in F9a are mmthick and composed of silt showing very angular clast. TOC content is low $(0.23-2.50 \%$, mean $=0.97 \%, N=12)$. The mudstone contains $50 \mathrm{~cm}$ wide, carbonate concretions, and minor bivalves and ammonite shells. Slumps, sand dykes and large scale syn-sedimentary faults occur. In addition, 5-10 m wide, shallow-marine olistoliths are observed within the mudstone. The olistoliths comprise massive finegrained sandstone, wackestone or mudstone. Bioturbation structures are absent in F9a, whereas mottlings are common in F9b (BI = 3-6) and no discrete trace is recognized (Fig. 14c, d).

This facies is interpreted as a slope mud belt (F9a) and a mixed slope (F9b). High-energy near-bed shear stress in the topset produced by wave, tidal and oceanographic currents generated mud bypass towards the deeper foreset area (Pirmez et al., 1998). Mixed sedimentation in coarsening upwards succession suggests minor scale sea-level changes, with the calcareous fine-grained sandstone representing increased siliciclastic export from the topset during sea-level lowstands (Kendall and Schlager, 1981; Yose and Heller,
1989). Angular shapes in clasts indicate eolian dust delivery caused the observed silt laminae, as eolian abrasion in silt-sized grains is relatively low (Kuenen, 1960). Other possible interpretations for the silt laminae as produced by current ripples flattened by compaction (cf. Yawar and Schieber, 2017) are less likely because of the absence of downlapping relationships in the laminae or erosive surfaces. Soft-sediment deformation structures and olistoliths originated from mass movements due to tectonic influence and slope construction. Along-shore redistribution by geostrophic currents (Swift et al., 1986), and across-shore sediment delivery by storm-ebb surge currents (Aigner, 1985; Snedden and Nummedal, 1990), hyperpycnal flows (Bhattacharya and MacEachern, 2009) and wave-enhanced sediment gravity flows (Wright and Friedrichs, 2006) transport mud to this area, yet structures associated with these processes were not observed. Compaction constitutes the main problem when analyzing fine-grained depositional environments because of their high water content at the time of deposition, and therefore, samples from carbonate-cemented concretions could be helpful to elucidate the relative importance of these processes (e.g. Otharán and Zavala, 2016). Existence of bioturbation structures in F9b indicates a change to oxic environments in the mixed slope. 

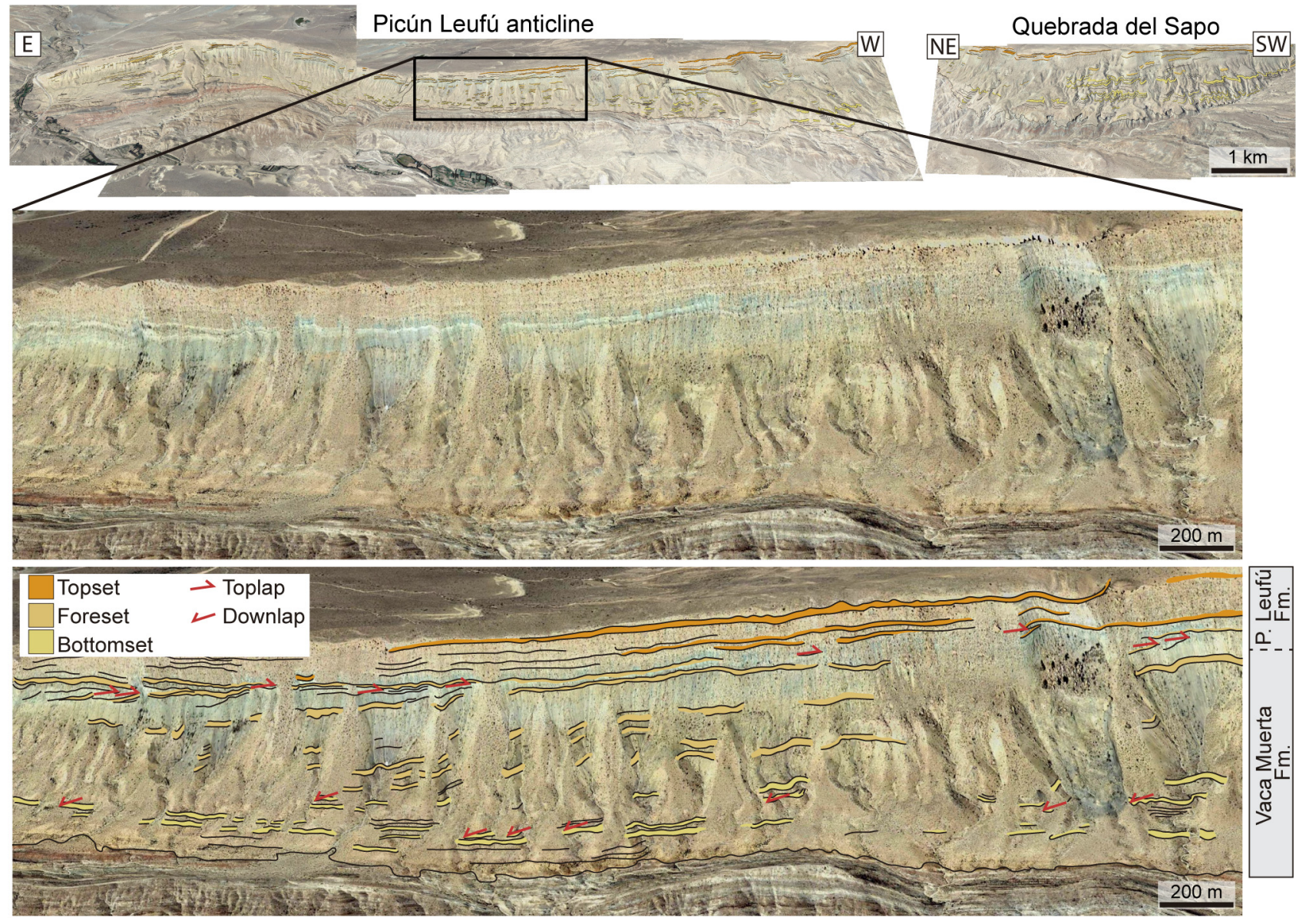

Fig. 13. Topset, foreset and bottomset geometries with their stratal terminations observed in satellite imagery of the Picún Leufú anticline and Quebrada del Sapo areas.

\subsubsection{Facies 10 (F10)}

This facies consists of thick- to medium-bedded (0.1-3 m), massive, calcareous fine-grained sandstone to intraclastic wackestone, intercalated with minor thin-bedded $(1-5 \mathrm{~cm})$, heterolithic intervals (Fig. 15a). Locally, subtle parallel lamination to low-angle cross stratification is observed. Some of the beds are amalgamated showing lenticular geometries with erosive bases. The sandstone contains minor isolated, small bivalve shells and mudstone rip-up clasts. This facies comprises 3-10 m thick intervals encased in facies F9 and located in a foreset position.

This facies is interpreted as foreset sand bodies produced by resedimented material from the shelf topset. The sand bodies are similar to the spillover lobes generated during times of strong tidal-ebb currents on the slope and consequent resedimentation in the foreset areas (Tucker and Wright, 1990; Playton et al., 2010), with sufficient energy to rework the muddy clinothem and transported it as rip-up clasts. The existence of faint sedimentary structures suggests development of concentrated density flows (Mulder and Alexander, 2001). Absence of well-defined structures precluded paleocurrent measurements and interpretation of likely triggering factors (wave, tidal or storm).

\subsubsection{Facies 11 (F11)}

This facies is composed of very thick successions $(1-3 \mathrm{~m})$ of medium- to coarse-grained, calcareous sandstone intercalated with medium- to thick-bedded $(0.1-1 \mathrm{~m})$, bioclastic wackestone and packstone (F11a, Fig. 15c) and erosive-based, thick-bedded (1-5 m), planar to trough cross-stratified, rudstone, floatstone and calcareous coarse- to medium-grained sandstone (F11b, Fig. 14a). F11a is mostly massive, although minor low-angle cross-bedding and wave ripples occur. F11b shows minor ripple cross-lamination showing escape trace fossils (Fugichnia) (Fig. 15d, e). Cross-stratification and lamination display paleocurrents towards SW and NE to E. The wackestone and packstone intervals are intercalated in the sandstones with gradational contacts. The matrix is composed by clay to fine-grained sand-size sediments, and the fossil content comprises articulated to disarticulated ammonites and bivalves (bioclastic fraction is 20-50\%). The bioclastic material is abundant in the rudstone and floatstone (80-70\%), and is composed of fragmented to partially preserved, disarticulated, large (up to $7 \mathrm{~cm}$ long) bivalve, gastropod and ammonite shells. Bioturbation completely reworked this facies (BI 4-6), giving a massive appearance, although Thalassinoides isp., Palaeophycus tubularis and horizontal to vertical undetermined trace fossils can be recognized (Fig. 14b). Burrow infill is commonly similar to the host rock, except for some grey mud infill.

This facies represents deposition in an oxygenated sandy shoal (F11a) with associated sand bars (F11b). The presence of trace fossils of a suspension feeding and active predator infauna in the calcareous sandstone (F11a) suggests suspended particles in a relatively moderate energy environment. Low-angle cross-bedding can be produced by bedform migration of the shoal edges (Ball, 1967), whereas wave ripples indicate oscillatory reworking in a relatively shallow environment. The packstone was produced during storm events due to the winnowing of the underlying sediment (Schlager, 2005), whereas the wackestone with clay matrix was generated during fair-weather times. High-energy currents scoured the underlying bioturbated sandy 


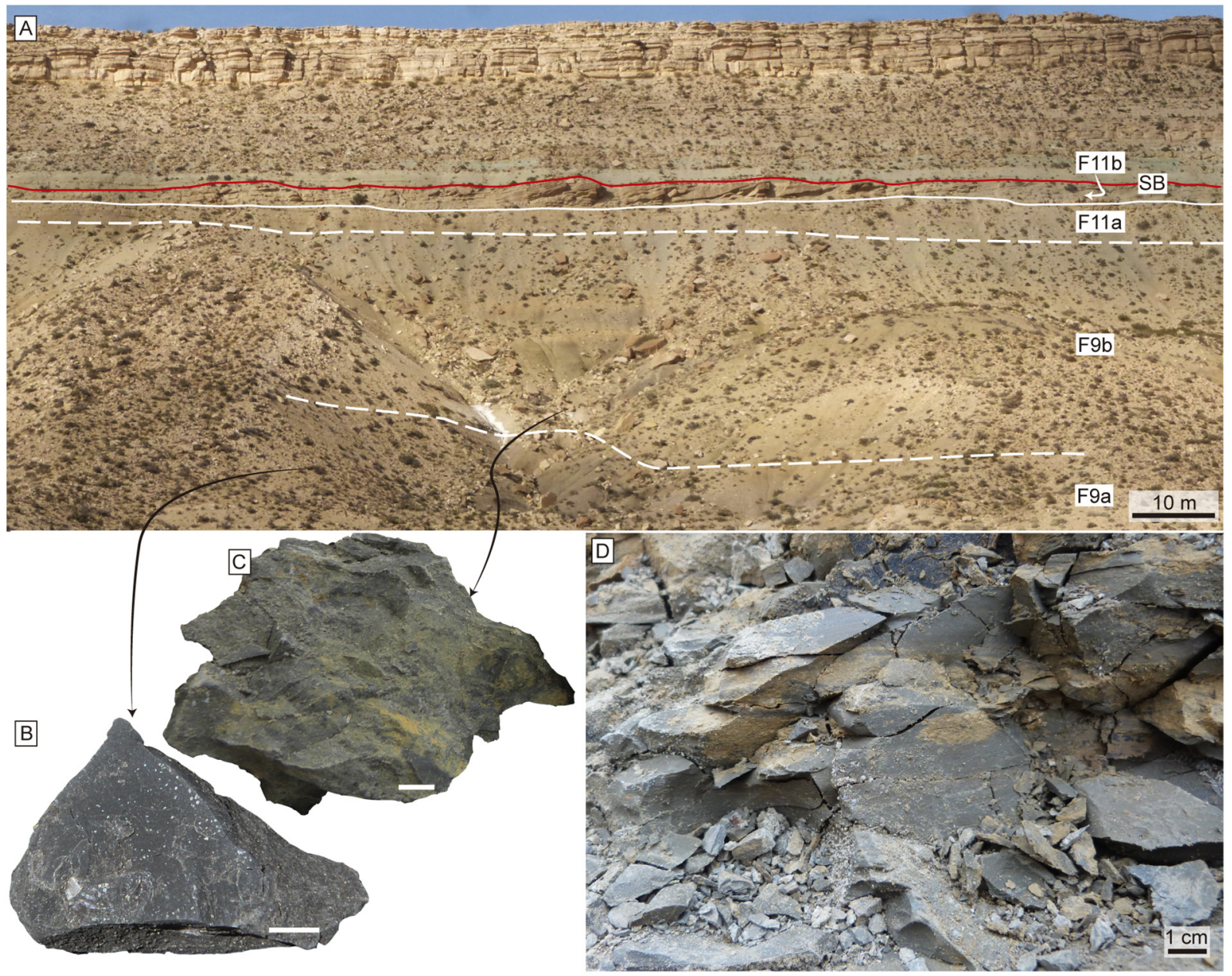

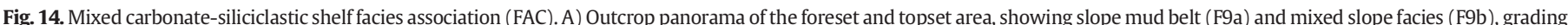

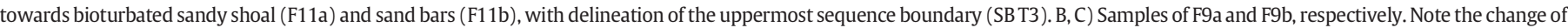

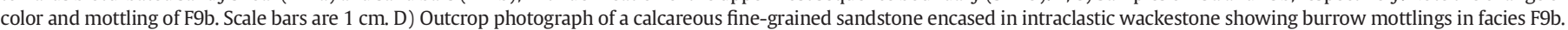

shoal deposits and generated migration of 2D and 3D subaqueous dunes (Hine, 1977; Tucker and Wright, 1990; Schlager, 2005). SW paleocurrents opposite to the direction of general coastal and clinothem progradation (NE) suggest a tidal influence in the origin of the bars (Spalletti et al., 2000). High energy levels and high sedimentation rate limited bioturbation, and therefore, trace fossils are excluded or represented only by escape structures in the sand bars (F11b).

\subsubsection{Facies 12 (F12)}

This facies is only recorded in the upper part of the Quebrada del Sapo section comprising a $\sim 4.5 \mathrm{~m}$-thick interval. It is composed by green, structureless to parallel-laminated, medium-grained sandstone. Isolated, up to $4 \mathrm{~cm}$ long, bivalve bioclasts are common. Bioturbation is represented by biodeformational structures (BI 0-2).

This facies is interpreted as a lagoonal deposit in a protected setting. The paucity of body fossils and bioturbation points towards an environmental stress caused by restricted water circulation.

\subsubsection{FAC interpretation}

The FAC represents the foreset and topset deposits of the mixed carbonate-siliciclastic shelf facies (Fig. 13). The FAC slope refers to a low-angle, shelf-prism slope $\left(0.91-1.15^{\circ}\right.$ angles observed in seismic reflections; Zeller, 2013) prograding into a relatively shallow basin floor comparable to an epicontinental shelf, instead of exemplifying the conventional usage of continental margin slope (see Patruno et al., 2015).

\section{Depositional model}

Analysis of sedimentological and ichnological datasets allows the proposal of a depositional model for the Vaca Muerta Formation and part of the Picún Leufú Formation in the study area (Fig. 16). Jurassic deformation generated a heterogeneous pre-Vaca Muerta relief, represented by an E-W topographic high located in the Picún Leufú anticline area (Zavala and Freije, 2002; Zavala et al., 2005, 2008; Naipauer et al., 2012). This high constituted an important controlling factor for open bay facies assemblage (FAA), which generated paleorelief smoothing through sediment shedding from topographically elevated areas towards depocenters. Consequently, the initial transgression generated thicker FAA deposits in low areas and thinner in high areas.

The relative sea-level rise started with a rapid upward migration of the water table in the Quebrada del Sapo eolian deposits (Fig. 16a), generating liquefaction of active coastal dunes. Coastal sand sheet and dunes (F1) were developed laterally from the soft-sediment deformation structures, where a high-water table restricted dune height, and constituted the first expression of the Vaca Muerta Formation.

Marginal marine (F2), bay margin (F3) and distal bay (F4) environments were developed in a low-energy, sheltered embayment area (Fig. 16a) weakly affected by waves. The distal bay deposits are only present in the Quebrada del Sapo area and section 1, probably due to its position as a topographic low with respect to the anticline. The area was 


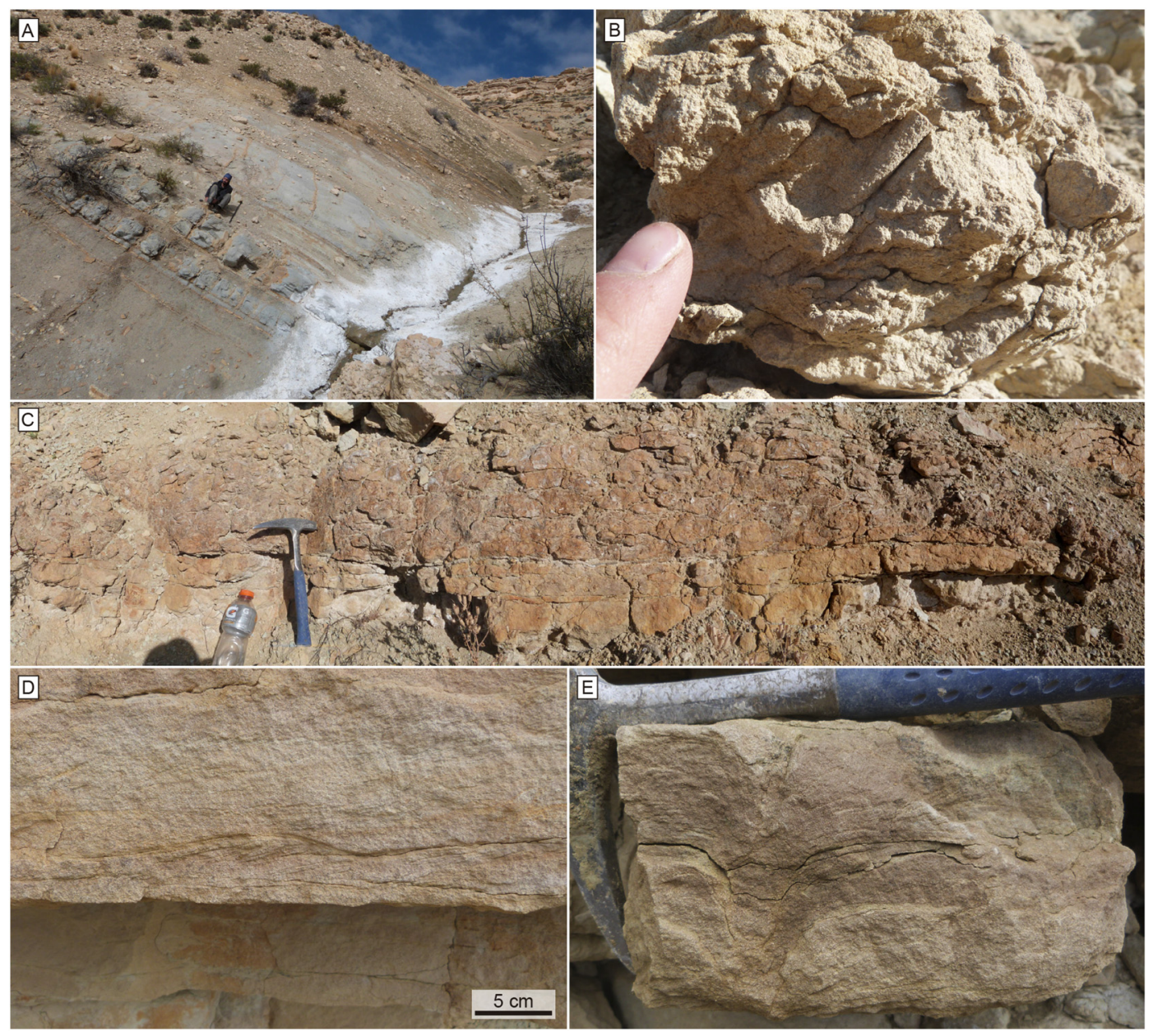

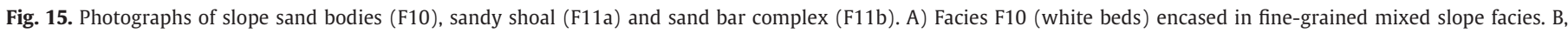

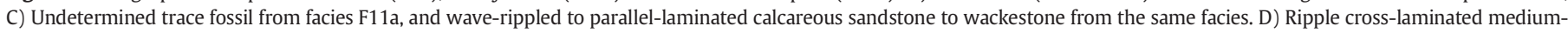
grained sandstone from facies F11b showing E) escape structures.

subject to suspension fallout sedimentation, punctuated by minor sandy concentrated density flows and muddy tempestite sedimentation. Opportunistic, low-diversity communities were sparsely developed in the distal bay, generating highly bioturbated intervals. On top of the FAA, a basinwide flooding led to deposition of the basinal facies (F5). The entire transgressive event ended with condensation and sediment starvation in the basin, leading to the formation of carbonate concretions.

After development of retrogradational FAA, alternating hemipelagic basinal (F5) and hyperpycnal flow sedimentation (F6 and F7) dominated in the bottomset area (Fig. 16b). Development of a low-angle coastal profile generated a basin of relatively shallow depth, allowing wave and combined-flow reworking of the hyperpycnal flow deposits. Oxygen-deficient conditions in the basin prevented bioturbation and produced short-term benthic colonization by bivalves during fluctuations of oxygen levels. In addition, the combined effect of oxygen deficiency and sediment starvation contributed to organic matter enrichment. Slumps were generated in a base of slope area by active tectonic deformation affecting the Picún Leufú anticline, which is recorded by the progressive unconformity lasting until the angular unconformity within the formation. Extensive slump and olistolith generation were produced nearby section 5 , where the Picún Leufú anticline showed its maximum deformation.

Wave-influenced hyperpycnal flows moving across-shelf (NE paleocurrents) punctuated hemipelagic deposition at the basin and contributed to siliciclastic dilution of organic matter content. Moreover, slump deformation indicates that turbidite flows probably affected the bottomset area. The hyperpycnal flows generated lobe fringe (F6) and lobe (F7) deposits that can be traced 5 to $10 \mathrm{~km}$ laterally, losing energy in a seaward direction. Therefore, lobe sedimentation was restricted to the landward sections (SW), and lobe fringe facies occur in the seaward sections (to the E). Amalgamation of hyperpycnal flow deposits occurred in the lobe area, whereas lobe fringe settings were subject to occasional flows alternating with basinal hemipelagic sedimentation (Fig. 9a). The continuous shifting of lobes generated thickening and coarsening upward patterns and controlled abandonment of lobe fringes seaward. The energy gradation of combined-flow structures from lobe fringe containing wave and combined-flow ripples, to the lobe area with HCS sandstone suggests reduced oscillatory energy in deeper lobe fringe positions. Sandy lobe fringe facies (F6a) encased in thick muddy lobe fringe deposits (F6b) shows the waxing and waning behavior represented by sandy and muddy hyperpycnal sedimentation. Evidence of flow regime fluctuations also occurs in the lobe facies (F7) with alternated S1 and S2 facies (sensu Zavala et al., 2011) and intrabed erosive surfaces. Absence of these wax and wane energy changes in some lobe and lobe fringe facies can be attributed to the pervasive reworking by wave and combined-flows.

The extensive lateral distribution of hyperpycnal sedimentation and common lack of vertical gradation or connection between lobe fringe and lobe facies is noteworthy. These observations can be related with (1) the low-frequency, intermittent nature of hyperpycnal deposition, 

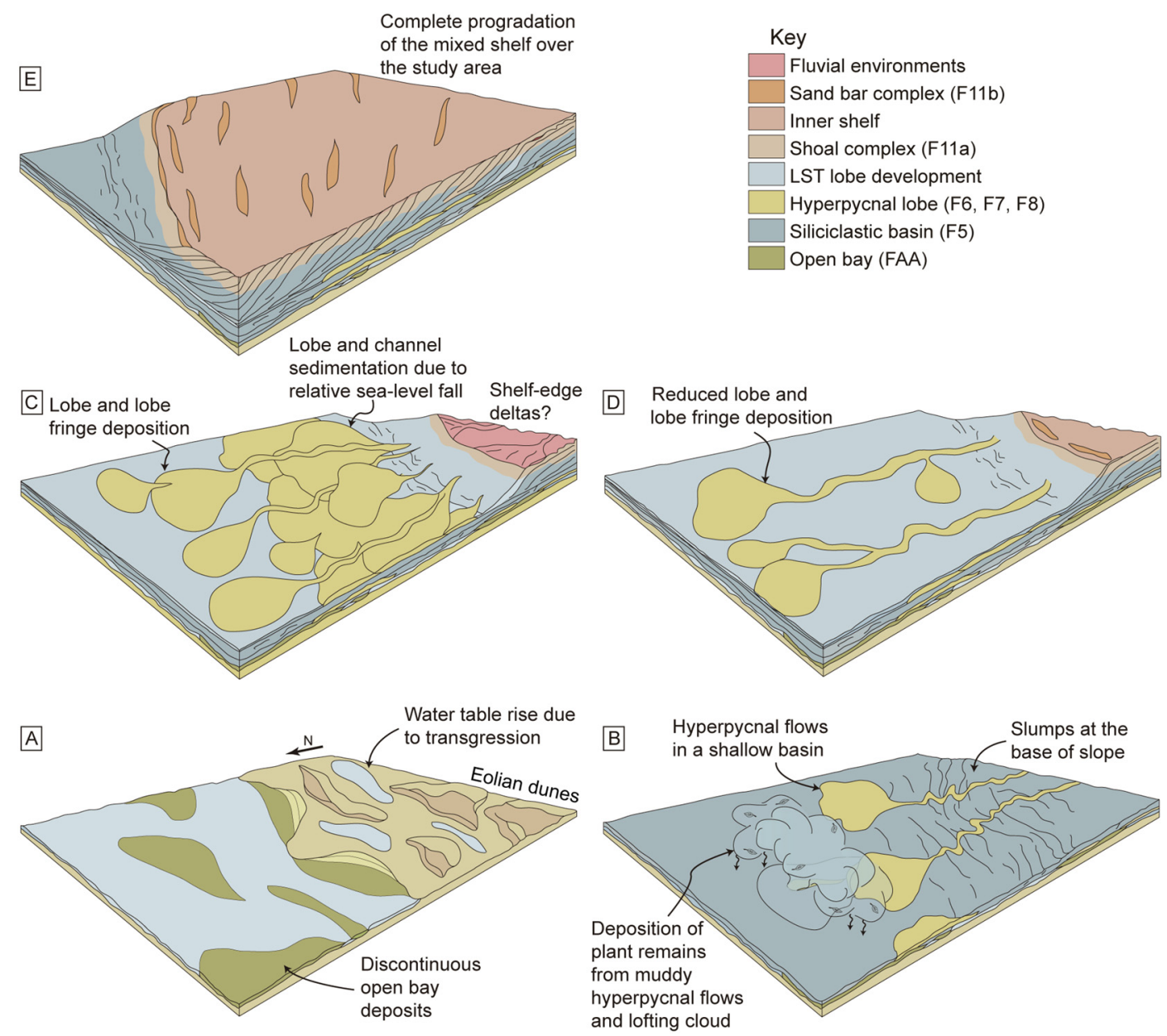

Fig. 16. Depositional model for the Vaca Muerta Formation (see text for explanation).

which is restricted to specific bottomset intervals associated with extraordinary river discharges, and (2) an angle-independent behavior of these flows, showing occurrences distally in the bottomset area in contrast with surge-like flows deposited near the base of slope (Zavala and Arcuri, 2016). The two probably source areas for these flows were the Somuncurá Massif to the SE, and the active Andean volcanic arc to the SW.

Rejuvenation of hyperpycnal sedimentation occurs after progressive anticline deformation ceased, and the angular unconformity was developed (Fig. 16c). Tectonic uplift related with the last phase of deformation at the end of progressive unconformity may have triggered baselevel changes. In this scenario, deltas approached to the foreset break and delivered high amounts of sediment to the bottomset, reactivating hyperpycnal sedimentation. Hydrodynamic energy decreased seaward, and therefore channel-fill (F8a), overbank (F8b) and lobe (F7) facies were produced at a base of slope position in the landward sections (SW), whereas lobe fringe facies (F6) occurs seaward in the basin (to the E). Facies F8a rests erosively on the underlying basin facies (F5) in the highly active tectonic area (section 5), where the higher energy facies occur. On top of facies F8a, hyperpycnal sandy deposits initiated a retrogradational pattern, displaying an increased amount of hemipelagic basin sedimentation (Fig. 16d).

The foreset area comprises clinoforms of the mixed carbonatesiliciclastic shelf (FAC) showing progradation towards the NE and downlapping relationships with the underlying bottomset strata (Fig. 13). These shelf-prism clinoforms developed a distinctive zonation of a topset, high carbonate productivity area, and a foreset showing mud belt accretion (Fig. 16e). The seaward area of the sections (sections 1 and 2) also developed minor bottomset basinal sedimentation during the beginning of clinoform progradation. Hyperpycnal sedimentation in the bottomset was restricted due to the evolution of the lower angle siliciclastic basinal system into a mixed carbonate-siliciclastic shelf prone to more sediment redistribution by coastal diffusion processes in a wider topset area. The addition of higher foreset angles to the mixed shelf system also prevented storm action in foreset and bottomset areas.

The lower foreset area comprises mud belt deposits (F9a) representing the shelf siliciclastic counterpart, whereas upper foreset and foreset to topset transition showed mixed siliciclastic carbonate sedimentation (F9b). Mass movements in the foreset generated slump and olistoliths, which are also more pervasive in the tectonically active area (section 5). Higher sedimentation rates of the foreset mud belt compared with those of the sediment-starved bottomset basin contributed to organic matter dilution. Rivers supplied siliciclastics towards the topset, which were later bypassed by across- and along-shore currents reaching the foreset. Sand bodies (F10) were an additional source of sediment, supplied from the shoal and sand bar complex (F11) located at the shelf break. The chemocline was located in the F9a-F9b transition and restricted bioturbation and organic matter preservation. The foreset-topset transition constituted an area of carbonate production with oxygenated waters, where organisms thrived and intensely reworked mixed slope facies (F9b) and sandy substrates of the sandy shoal (F11a). The sand bars (F11b) protected the lagoon in the topset and represented a sediment source as well. Bioturbation was precluded 


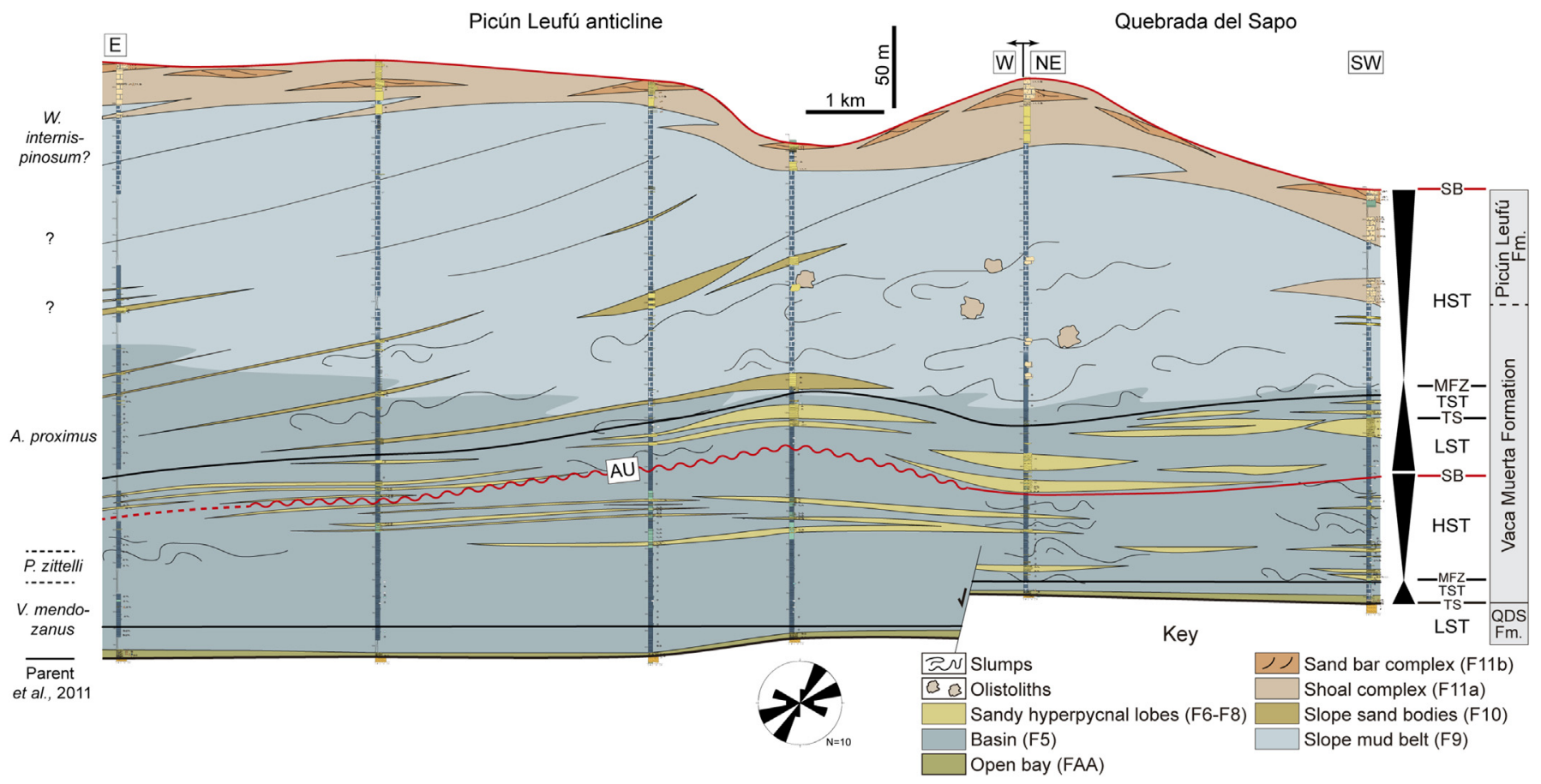

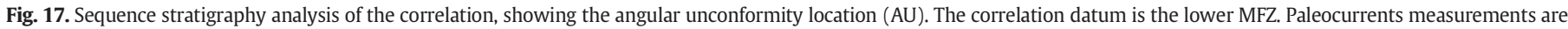
restricted to F6a and $\mathrm{F} 7$.

in the lagoon (F12) or restricted to escape structures in the sand bars due to salinity and sedimentation rate stresses, respectively. The whole FAC sedimentation ended with an erosional surface recording erosion of the foreset and truncation towards topset structures (Fig. 14a).

\section{Sequence stratigraphy}

The sequence stratigraphy analysis of the correlation panel is presented in Fig. 17. The analysis follows Depositional Sequence Model II of Posamentier et al. (1988), to avoid confusion with delineation of a Falling Stage Systems Tract (FSST). The ammonite biostratigraphic zonation of Riccardi (2008), following Parent et al. (2011) analysis in the easternmost of our sections was utilized to calibrate chronostratigraphically the correlation, although the proposed new zone (Picunleufuense) is not used due to a lack of consensus (cf. Riccardi, 2008, 2015). Progradation or aggradation of lobe deposits were considered as product of autocyclic changes, as they are likely generated either by lobe migration or aggradation and progressive smoothing of the depositional surface (Mutti and Sonnino, 1981), or by changes in the fluvial input related with climatic factors (Zavala and Arcuri, 2016). Two depositional sequences (DS1 and DS2) were recognized in the study area.

\subsection{Depositional Sequence 1 (DS1)}

The base of DS1 is placed at the base of the Quebrada del Sapo Formation LST deposits. The first expression of marine facies of the Vaca Muerta Formation indicates the development of a Transgressive Surface (TS) located on top of eolian dune facies and deflation surfaces of the Quebrada del Sapo Formation (Fig. 6a, b). On top, FAA shows a retrogradational stacking pattern and constitutes the TST. Bay margin facies (F3) represent wave reworking and therefore, a wave ravinement surface is developed at the base. The TST is within the $V$. mendozanus ammonite zone, which has been assigned to the late early Tithonianearly middle Tithonian. The maximum flooding zone (MFZ) is suggested by the extensive occurrence of carbonate concretions indicating condensation and high TOC values within basin facies (F5) and marks the top of the TST.

Above the MFZ, facies F5 shows coarsening upwards cycles, and the first hyperpycnal facies occur, indicating the beginning of HST. At a larger scale, a progradational $55-110 \mathrm{~m}$-thick siliciclastic basin facies assemblage (FAB) is observed. The HST was deposited during the middle Tithonian, constituting the upper $V$. mendozanus, the $P$. zittelli and the lower A. proximus ammonite zones.

\subsection{Depositional Sequence 2 (DS2)}

The angular unconformity within the Vaca Muerta Formation occurs at the $80-120 \mathrm{~m}$ of the section (Figs. 4 and 18, "AU"), representing the end of the progressive unconformity affecting the anticline. Above the angular unconformity, the abrupt reactivation of sandy hyperpycnal flow facies and existence of shallow-water wave and storm reworking suggest a relative sea-level fall associated with a Sequence Boundary (SB) and LST sedimentation, marking the beginning of DS2. The coincidence of the angular unconformity with the SB indicates tectonic movements along the anticline could be associated with base-level and accommodation space changes. Hyperpycnal facies (F6, F7 and F8) overlaying the LST display retrogradational stacking patterns with increased deposition of F5, indicating a TST developed upon a transgressive surface (TS). The LST and TST are $25-50 \mathrm{~m}$ thick and are middle Tithonian in age based on the A. proximus ammonite zone location. The MFZ occurs at the top of the TST and is suggested by carbonate concretions and higher TOC values within F5 interval.

The overlying mixed carbonate-siliciclastic shelf (FAC) facies display foreset geometries prograding towards the NE with downlap relationships with the MFZ, as revealed in outcrop and seismic images (Fig. 13), indicating development of HST (DS2). The HST comprises the $A$. proximus to $W$. internispinosum ammonite zones, suggesting a middle to late middle Tithonian age. The foreset shows a significant lateral thickness variation from NE to SW of $\sim 254$ to $~ 119$ m caused by an irregular truncation surface at the top, which deepens towards the SW and represents a SB (Figs. 14a, 16). 


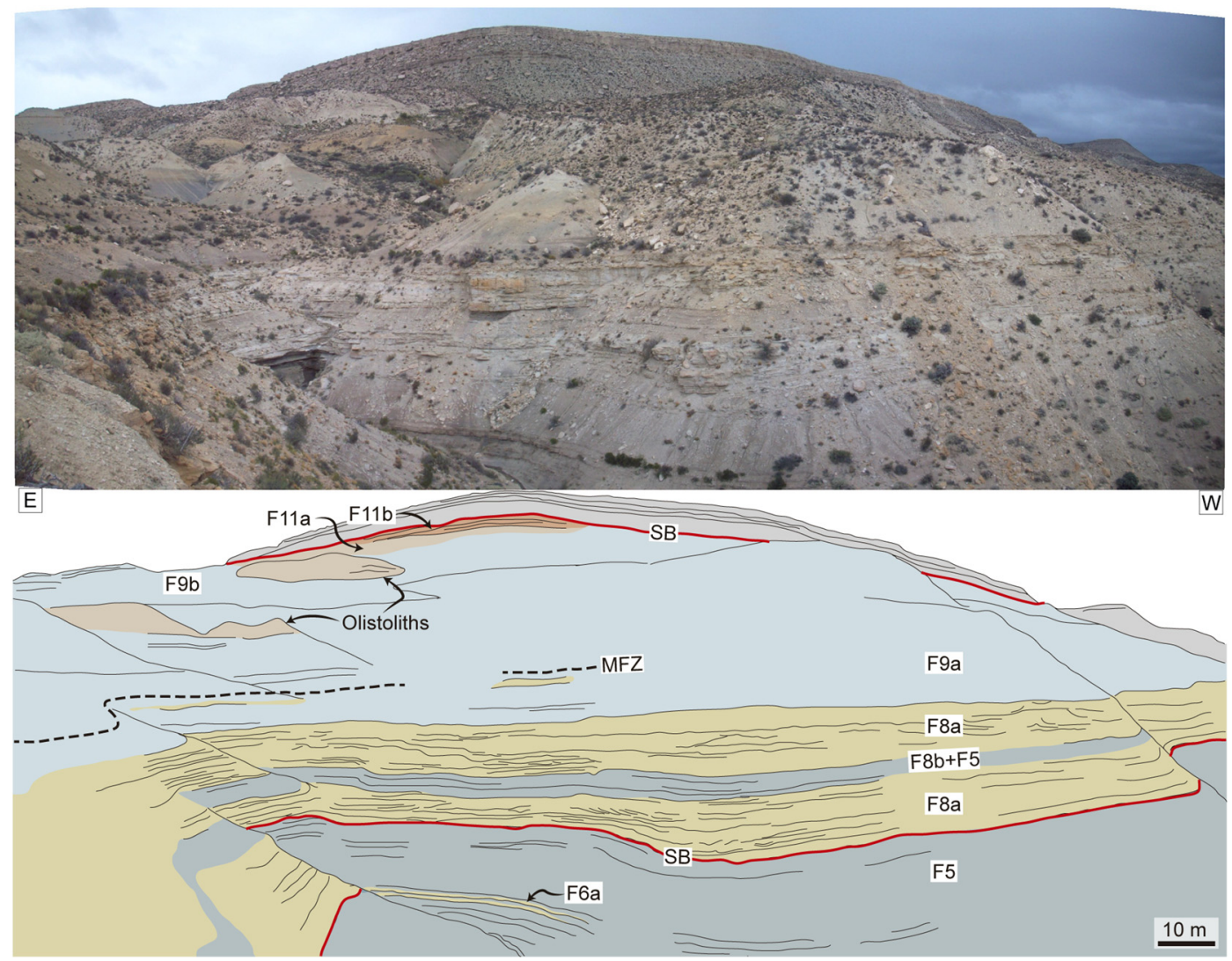

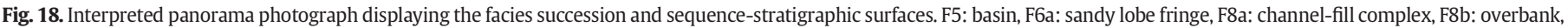
F9a: slope mud belt, F9b: mixed slope, F11a: bioturbated sandy shoal, F11b: sand bar complex.

6.3. Correlation of outcrop-based sequence stratigraphy with seismic section

The sequence stratigraphy analysis from outcrops was correlated with the seismic section from Zeller (2013) and Massaferro et al. (2014), which is parallel to our outcrop section (Fig. 19). The seismic section clearly differentiates bottomset, foreset and topset reflectors. The bottomset displays continuous reflectors in its lower and upper part, and a lowamplitude middle part, which has subtle downlapping relationships with the lower bottomset. The bottomset thins basinward, towards the NE. The foreset reflectors are above the bottomset, showing mostly downlap terminations towards the upper bottomset top, with minor internal downlap and onlap surfaces. At the top, the foreset-topset contact constitutes an irregular truncation surface that is dipping towards SW, underlying a topset composed by continuous horizontal reflectors.

The correlation from outcrop to seismic was created adjusting the thickness of the easternmost Picún Leufú section to the NE edge of the seismic line, tying the TS to the Vaca Muerta Formation base, and the uppermost SB to the foreset truncation surface. The Picún Leufú section was chosen for being a more homogeneous depositional environment with less hyperpycnal flow sedimentation, and its proximity with the seismic section. After adjustment, bottomset and foreset outcrop geometries match with the seismic image. The lower bottomset correlates with TST (DS1), and the middle low-amplitude bottomset corresponds to the HST (DS1) siliciclastic basin (FAB) sedimentation. The upper bottomset coincides with LST and TST (DS2) position: the base matches with SB (DS2), whereas the top, which is a downlap surface, correlates with MFZ (DS2). The continuity of the upper bottomset reflectors with an absence of terminations (Fig. 19b) supports its correlation with an aggradational-retrogradational LST and TST. HST (DS2) shows foreset reflectors in a landward position and bottomset reflectors seaward, both of them downlapping over the MFZ (DS2). On top, the truncation surface is highly irregular, similarly as it is observed in outcrops.

\section{Discussion}

\subsection{The hyperpycnal sedimentation model for basinal sand deposits}

Analysis of sedimentological evidence of the basinal sandstone intervals hereby described (F6, F7 and F8) indicates a wave-influenced hyperpycnal flow origin for most of the turbidity and concentrated density currents responsible for sedimentation. Three models are meaningful in the discussion of the origin of these deposits: waning flow model (Kneller, 1995; Mulder and Alexander, 2001), tempestite model (Aigner, 1985; Myrow and Southard, 1996), and hyperpycnal flow model (Mulder et al., 2003; Zavala et al., 2011), and these are revised in detail in the following paragraphs.

The waning flow model follows the classic turbidite model proposed by Bouma (1962), which was intended to explain the processes and products of waning, unidirectional turbidity flows. These flows are differentiated from hyperpycnal flows mainly by the steadiness of sedimentation: while hyperpycnal flows are considered quasi-steady currents, waning flows are unsteady flows (Mulder and Alexander, 2001). Many factors can trigger waning flows, although commonly they are related to slumping produced by gravity-collapse or seismogenic activity. The model is useful to explain the occurrence of erosive bases and unidirectional structures in the sandstone, yet fails to account for the riverine signal provided by the plant debris occurrence and the wave and combined-flow reworking.

Second, the tempestite model explains deposition of stormgenerated beds across the shelf, in offshore areas (Aigner, 1985; Myrow and Southard, 1996). The possibility for a density flow to be 

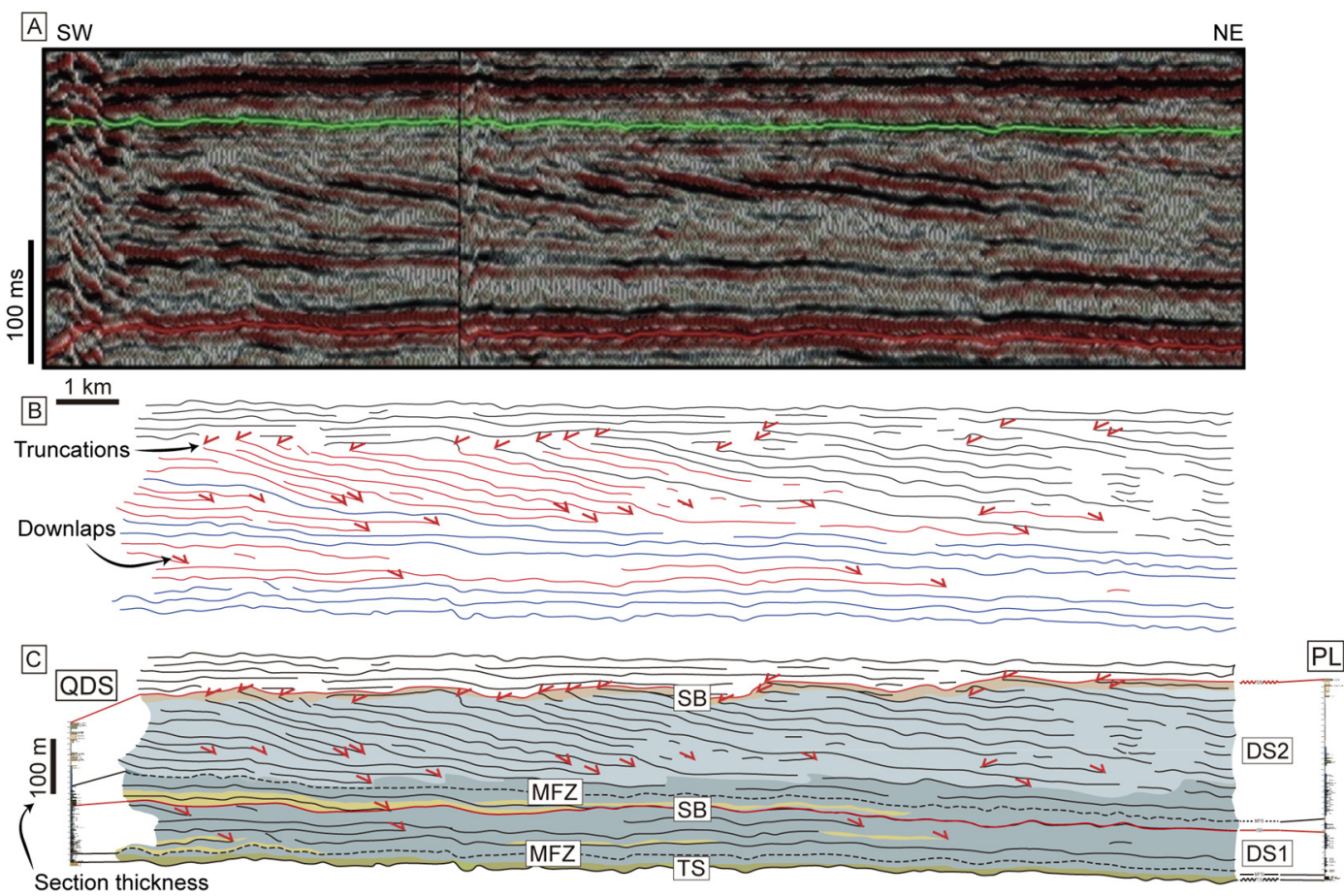

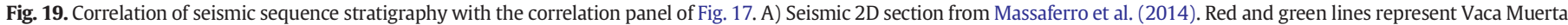

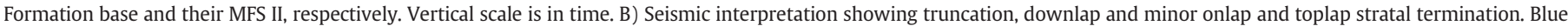

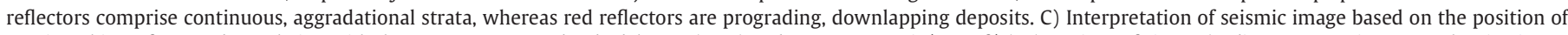

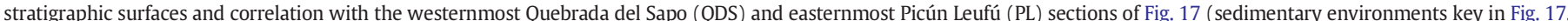

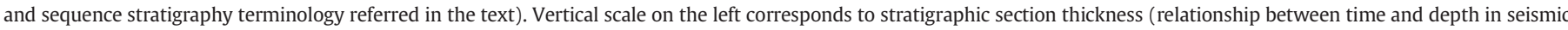
line is unknown). (For interpretation of the references to color in this figure legend, the reader is referred to the web version of this article.)

offshore-transported is controlled by the interplay between offshore pressure gradient, Coriolis forces, bottom friction and excess-weight forces (Myrow and Southard, 1996). Offshore pressure gradient is produced by coastal set-up and set-down generated by storm wind energy, which consequently trigger currents that are deflected along-shore by Coriolis forces (geostrophic flows, Swift et al., 1986). Excess-weight forces refer to the downslope force produced by a sediment suspension, and its magnitude is related with sediment concentration and the available slope. High offshore pressure gradient, high excess-weight forces and weak Coriolis forces facilitate across-shelf sediment transport; however, high excess-weight forces achieved by catastrophic introduction of sediment are particularly emphasized by Myrow and Southard (1996) as a likely triggering factor. These authors suggested that many tempestites represent across-shelf transport during storms with high bottom sediment concentration, with the sediment-rich suspensions being provided by river floods or earthquakes. Consequently, this model can successfully interpret the storm (wave and combined-flow structures and gutter casts) and riverine input (plant debris), evidence of our basinal sandstone facies.

Lastly, hyperpycnal flows are negatively buoyant, freshwater density underflows generated during times of river flood (see Mulder and Syvitski, 1995; Mutti et al., 1996; Mulder et al., 2003; Ponce, et al., 2008; Zavala et al., 2011; Wilson and Schieber, 2014; Canale et al., 2015; Zavala and Arcuri, 2016). Negative buoyancy is easily achieved in freshwater bodies, yet in marine settings, the concentration of suspended sediment in the flows needs to be large enough in order to overcome seawater density (Mulder and Syvitski, 1995). These flows differ from waning flows by the duration and steadiness of the event: hyperpycnal flows are originated by a continuous fluvial discharge that may last for days or weeks, which generates a quasi-steady current, whereas waning, surge-like flows are very short duration, unsteady and strongly non-uniform events (Mulder and Alexander, 2001). Hyperpycnal flow deposits display a typical coarsening-up to fining- up trend as a result of the waxing-waning behavior of the fluvial discharge (Mulder et al., 2003), which contrasts with the waning, surgelike turbidite sequence. In addition, hyperpycnal flows are able to transport extrabasinal material as plant debris in their suspended load (Ponce and Carmona, 2011a,b; Zavala et al., 2012; Canale et al., 2015). Hence, the hyperpycnal model can account for the abundance of plant debris in our basinal sandstone deposits.

Following these definitions, a combination of the tempestite and hyperpycnal flow models can explain the evidence detected by our analysis. As pointed out before, evidence of flow regime fluctuations occurs in the lobe facies (F7), and lobe fringe facies (F6). Typical waxing and waning flow sedimentary structures are not observed in the lobe fringe sandy facies, probably due to the pervasive reworking by waves and combined-flows and the abundance of massive beds. Nevertheless, massive bed deposition do not exclude interpretation of river-derived flows, as structureless beds produced by hyperpycnal flows occur in Holocene subaqueous fans in southern California (Steel et al., 2016).

The high amount of plant debris constitutes a direct evidence suggesting a connection with riverine systems (Plink-Bjölrklund and Steel, 2004; Ponce et al., 2008; Mulder and Chapron, 2011; Paim et al., 2011; Ponce and Carmona, 2011a,b; Zavala et al., 2011; Zavala and Arcuri, 2016). Not only plant debris have been extensively found in the fine-grained deposits, but also randomly disposed in the sandstone and draping sandstone parallel lamination. In addition, it is difficult to explain the abundant plant remains in the mudstone facies as being reworked from prodelta or delta front deposits, as biological and physical reworking contributes to oxidize the organic material deposited in these areas (Zavala and Arcuri, 2016). However, abundant slump structures indicate turbidite flows probably contributed to bottomset sedimentation.

These hyperpycnal flow deposits were reworked by wave and combined flows during storms in a shallow basin. Storm imprint in hyperpycnal facies was only possible during siliciclastic basin 
development (HST of DS1, and LST and TST of DS2) due to its gentler angle of slope compared with mixed shelf systems and consequent lower water depth. Other possible origins to consider for combinedflows include internal waves associated with density contrast in the upper interface of the flows (Mutti et al., 1996), or reflection and ponding processes by flowing against obstacles (Edwards et al., 1994, Kneller et al., 1997). The storm-generated combined-flow hypothesis is the most plausible explanation due to (1) the genetic association with oscillatory flow reworking, which may reflect a decelerating later phase of the unidirectional component and consequent shift to pure oscillatory movement, and (2) the existence of combined and/or oscillatory flow reworking in mostly every bottomset sandstone bed, suggesting deposition above storm wave base.

Therefore, the basinal sandstone facies are interpreted as waveinfluenced hyperpycnites produced by sediment-rich riverine discharges during a superimposed storm event. Shore-perpendicular paleocurrents suggest offshore-directed sedimentation and exclude the hypothesis of along-shore geostrophic currents. Studies on modern continental shelves showed that sediment gravity flows are of prime importance in distributing sediment across-shelf (Hill et al., 2007), with some examples associated with fluvial discharges (Wright and Friedrichs, 2006; Ma et al., 2008). Boundary shear stress produced by storm-generated waves or currents aid to sustain suspended sediment and maintain negative buoyancy (Wright et al., 2001; Wright, 2012). Sediment suspensions generated during storms without associated riverine discharge were probably deflected by along-shore currents and contributed to foreset construction landward from the study area. The superimposed storm-generated, wave and combined-flow action over a sandy sediment-gravity flow associated with fluvial discharges has been described in the fossil rock record as a wave-modified (or waveinfluenced) turbidite (Myrow et al., 2002, 2008; Higgs, 2004; Pattison,
2005; Pattison et al., 2007; Lamb et al., 2008; Pattison and Hoffman, 2008; Buatois et al., 2019) or shelfal hyperpycnite (Zavala et al., 2011).

7.2. Sedimentary and sequence stratigraphic models: Regional and global importance

Bottomset and foreset represent two contrasting areas of deposition, impacting on siliciclastic, organic matter and carbonate accumulation (Fig. 20). The bottomset area was characterized by extensive sediment-starvation and oxygen deficiency, allowing higher organic matter concentration produced by hemipelagic sedimentation. The absence of bioturbation and an abundance of pectinid bivalves indicate this environment could represent the exaerobic zone of Savrda and Bottjer (1987), where low oxygen bottom waters coexist with reducing substrates, contrasting with trace element geochemistry that suggests oxic bottom waters and reducing pore waters (Krim et al., 2017). The mudbelt accretion and eolian input contributed to dilution of organic matter in the foreset. These models are similar to the mudbelt and sediment-starved shelf descriptions of Birgenheier et al. (2017) for the Mancos Shale, USA, with their limit representing the most seaward extension of mud delivery by coastal redistribution processes.

In addition, slumping and olistolith formation related with tectonic activity represented an important sediment contributor to both bottomset and foreset areas. Tectonic movements along the Picún Leufú anticline affected early development of the siliciclastic basin (Krim et al., 2017) up to the end of HST (DS1), and also during SB and LST (DS1) formation. Krim et al. (2017) located slumps as a facies association on top of their high-frequency cycle S2 and related them with a gently prograding slope. However, random slump distribution in both bottomset and foreset positions and association of the siliciclastic basin with a progressive unconformity suggest a mixed sedimentary

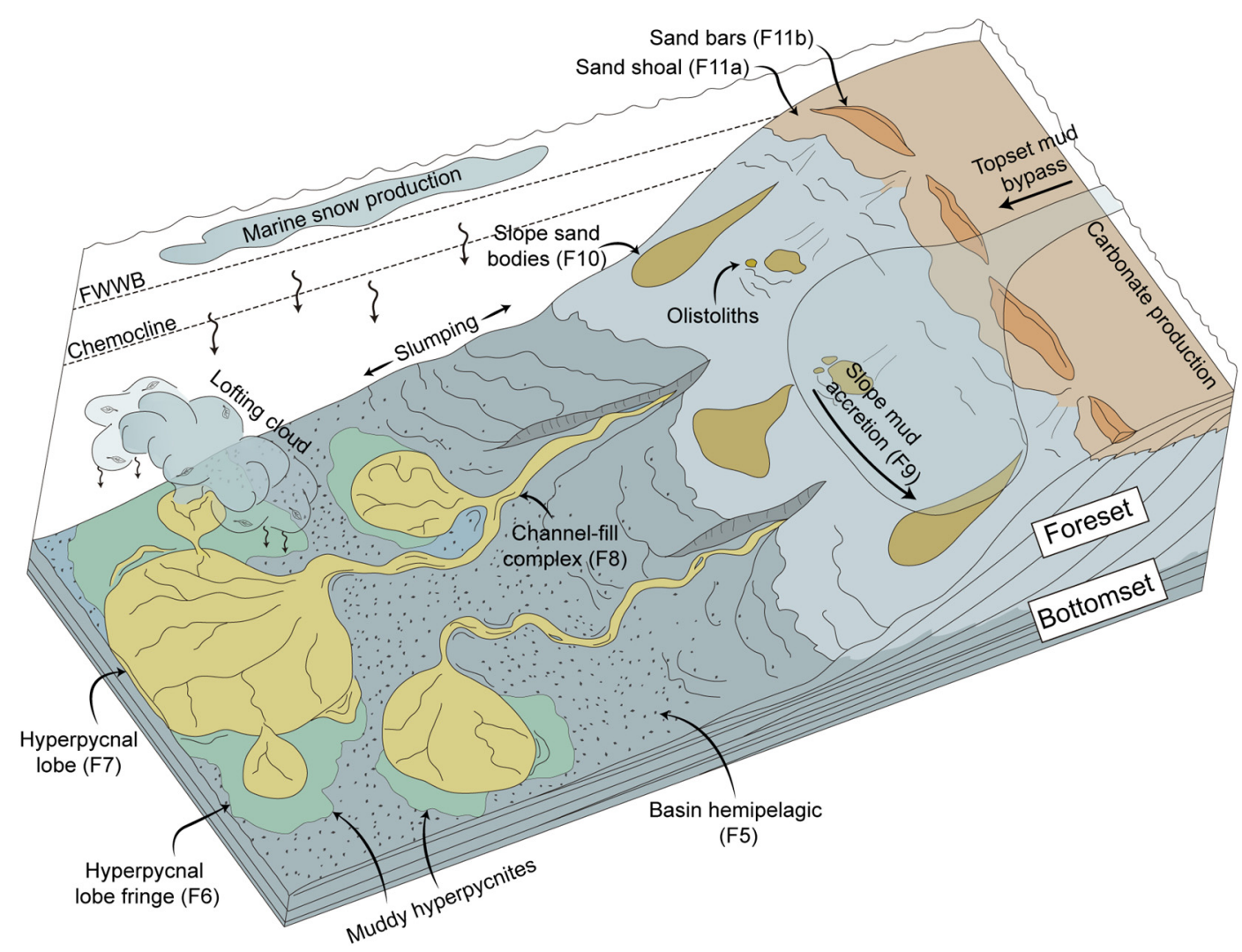

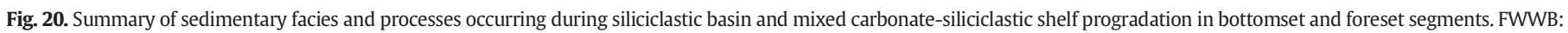
Fair-weather wave base location. 
and tectonic origin for the slope triggering slump deformation. Slumps and other deformational structures were also documented at the bottomset-foreset transition in seismic sections from the central Neuquén Basin (Pose et al., 2014; Arregui, 2014; Notta et al., 2017; Reijenstein et al., 2017). In addition, hyperpycnal and minor surge-like flows also contributed to bottomset sediment accumulation. Otharán et al. (2016) recognized the sandstone deposits as produced by shelfal hyperpycnal flows, a similar interpretation to the one favored here.

Delineation of the base of DS2 described in the present contribution agrees with the "SB2" proposed by Spalletti et al. (2000), and the "discontinuity 8" described by Freije et al. (2002). In addition, this SB coincides in age with the T2 surface recognized in seismic analysis (Desjardins et al., 2016), yet regional seismic correlation of stratigraphic surfaces is needed to confirm this hypothesis. Seismic information provided by Massaferro et al. (2014) and outcrop delineation of facies geometry also support SB interpretation. The correlation with the seismic section was helpful to confirm the location of the conformable, non-erosive SB seaward, in an area where absence of abrupt facies changes makes its recognition difficult. This sequence stratigraphic interpretation adds more detail to bottomset reflectors analysis in seismic, which were described as a transgressive succession (Massaferro et al., 2014).

LST (DS2) shows extensive hyperpycnal flow sedimentation in both bottomset to foreset positions. These LST sandstone intervals from the Quebrada del Sapo section were correlated with the LHo.x-1 well log, located $35 \mathrm{~km}$ southeast from the area (Santiago et al., 2014), and also interpreted as turbiditic resedimentation processes in a slope setting (Otharán et al., 2017). Slumps and water escape structures support the existence of a slope, yet the seaward association of high-energy LST facies with lobe fringe, plant debris-rich deposits, probably indicates an extrabasinal origin.

Carbonate productivity increased during HST (DS2) and was exported towards the foreset. Siliciclastic elements were probably fed by riverine buoyant plumes bypassing the high-energy topset and contributing to clinothem progradation in deeper areas. Alternation of HST carbonate and TST siliciclastic deposition were explained by an alongshelf current system redistributing sediment during TST and being terminated during HST by a lack of accommodation space in the shelf topset (Zeller, 2013; Zeller et al., 2015b). In addition, several authors described the tidal influence of the system (Spalletti et al., 2000; Armella et al., 2007; Zeller et al., 2015b; Krim et al., 2017) and associated this process to tidal amplification caused by the embayed geometry of the Neuquén Basin and existence of the Huincul Ridge (Spalletti et al., 2000). Evidence presented in this contribution underscores the action of fluvial input in the bottomset showing across-shore paleocurrents, expanding and modifying the knowledge of sedimentary processes affecting the system.

Presence of a slope with olistoliths and pervasive slumping, and absence of a clear and graded outer-mid-inner ramp partitioning lead us to utilize the shelf terminology instead of ramp. The system has been also considered as a gently inclined shelf (Zeller, 2013; Zeller et al., 2015b), which might be a reasonable alternative terminology. The foreset and foreset-topset transition ended with a SB truncating HST (DS2) on top correlated with surface T3 of Desjardins et al. (2016), that has been also observed in seismic section and correlation with outcrops from Sierra de la Vaca Muerta (Zeller, 2013; Massaferro et al., 2014).

The analysis of bottomset and foreset sedimentary processes in the Vaca Muerta Formation has implications for understanding shelfal sand sedimentation in sequence stratigraphic models and organic matter enrichment in one of the most important unconventional reservoirs in the world (cf. Wang et al., 2016). Warrick et al. (2013) and Steel et al. (2016) described sandy hyperpycnites in the modern Santa Barbara channel, USA, indicating sandy shelfal sedimentation disconnected from offshore tempestite processes was not restricted to LST deposition or TST shelf sand ridges (Berne et al., 1998; Snedden and Dalrymple, 1999), as conventional sequence stratigraphic models suggest (Posamentier and Vail, 1988; Catuneanu, 2006). Similarly, the Vaca Muerta sandy shelfal sedimentation shows en masse deposition of wave-enhanced currents with massive beds and dewatering structures during HST and additionally, LST development. Therefore, the Vaca Muerta Formation represents a direct fossil example of the Santa Barbara channel deposits that occur in bottomsets associated with short topset distances able to bypass the littoral energy fence.

In addition, organic matter distribution in this unconventional reservoir shows a clear pattern affected by dilution of siliciclastic material. Organic matter enrichment constitutes a process balanced by the effects of dilution by inorganic components, production and preservation of organic matter (Tyson, 2005), and the question of which of these processes represents the main driving factor constitutes an extensive debate (Hedges and Keil, 1995; Sageman et al., 2003; Katz, 2005; Macquaker et al., 2010). Recently, many studies underscored the contribution of sediment-density flows in trapping organic matter towards deep, fine-grained depositional environments (Könitzer et al., 2014; Lash, 2016, DeReuil and Birgenheier, 2019), in addition to studies from the Vaca Muerta Formation (Otharán and Zavala, 2018). The present analysis shows low TOC content associated with buoyant plume (minor massive fine mudstone in facies F5) and fine-grained hyperpycnal flows (facies F6b) deposits in the bottomset, and with mudbelt (facies F9a) deposits in the foreset, suggesting that, dilution of sediment-starved, hemipelagic basinal areas constitutes the main controlling factor for organic matter enrichment in the study area. However, more analysis focused on the organic matter quality and type should be conducted to fully understand the processes of organic carbon burial in the Vaca Muerta Formation.

\section{Conclusions}

Two third-order sequences (DS1 and DS2) representing bottomset, foreset and foreset-topset transition sedimentation accumulated in the Vaca Muerta Formation. TST (DS1) started with deposition in an open bay setting, represented by coastal sand sheet and dune, marginal marine areas, bay margin and distal bay environments showing retrogradational patterns, and ended during a MFZ developed within a sediment-starved basin. Bioturbation suggests firmground conditions in the bay margin and opportunistic behaviors in the distal bay. HST (DS1) records hemipelagic deposition in a shallow, sediment-starved basin, punctuated by wave-influenced, hyperpycnal lobe and lobe fringe sedimentation and minor turbidite flows. A progressive unconformity affected the anticline area until the end of DS1. An angular unconformity separates DS1 and DS2, constituting a SB. DS2 started with LST deposition of wave-influenced, hyperpycnal channel-fill complex, lobe, and lobe fringe facies, and ended with retrogradational hyperpycnal facies encased in basin deposits during TST. LST and TST deposits correlate in seismic sections with two continuous bottomset reflectors, indicating large-scale aggradational stacking patterns during their development. HST (DS2) developed the foreset mixed carbonate siliciclastic shelf, associated with slope mud belt and slope sand body facies. The foresettopset transition constituted a low-energy, bioturbated sandy shoal crosscut by high-energy, sand bar complexes, with minor laterally associated, lagoonal deposits. The chemocline marks the transition between unbioturbated muddy slope facies and bioturbated mixed slope facies. Bioturbation occurs as a burrow mottling in the mixed slope, massive structures in the sandy shoal or as escape structures in high-energy bar facies. The foreset deposits ended by a truncation on top, representing an erosive SB. Based on the Vaca Muerta Formation time frame, the stratigraphic surfaces bounding the two third-order sequences could be correlated with T1 and T3 surfaces of the regional sequence stratigraphic framework. 


\section{Acknowledgments}

We thank to Martin Parada, Debora Campetella, Maximiliano Rodríguez and the Painemilla family, who were of exceptional support in the Picún Leufú village field work, Fernando Valencia for his help with thin section descriptions, the feedback provided by C. Zavala to an early draft, and the valuable comments of reviewers Lauren Birgenheier and Massimo Moretti. This work was financially supported by the Natural Sciences and Engineering Research Council of Canada (NSERC), PI 40A-468 IA 1 from the Universidad Nacional de Río Negro (UNRN), 2016 Student Research Grant from Society for Sedimentary Geology (SEPM), 2016 Research Grant from the Geological Society of America (GSA), and 2016 Grants-in-Aid Program of the American Association of Petroleum Geologists (AAPG). E.P thanks the CNPq and FAPERJ by financial support.

\section{References}

Aigner, T., 1985. Storm Depositional Systems: Dynamic Stratigraphy in Modern and Ancient Shallow Marine Sequences. Springer, Berlin 174 pp.

Armella, C., Cabaleri, N., Leanza, H.A., 2007. Tidally dominated, rimmed-shelf facies of the Picún Leufú Formation (Jurassic/Cretaceous boundary) in southwest Gondwana, Neuquén Basin, Argentina. Cretac. Res. 28, 961-979.

Arregui, C., 2014. Ciclos deposicionales de las Fms Quintuco y Vaca Muerta: Génesis y evolución. Área Central - Cuenca Neuquina. In: IX Congreso de Exploración y Desarrollo de Hidrocarburos, Mendoza, Argentina, pp. 189-207.

Arregui, C., Carbone, O., Leanza, H.A., 2011. Contexto tectosedimentario. In: Leanza, H.A. et al. (Eds.), Relatorio Del XVIII Congreso Geológico Argentino, pp. 29-36.

Ball, M.M., 1967. Carbonate sand bodies of Florida and the Bahamas. J. Sediment. Petrol. 37, 556-591.

Bates, C.C., 1953. Rational theory of delta formation. Am. Assoc. Pet. Geol. Bull. 37 2119-2162.

Berne, S., Lericolais, G., Marsset, T., Bourillet, J.F., De Batist, M., 1998. Erosional offshore sand ridges and lowstand shorefaces; examples from tide- and wave-dominated environments of France. J. Sediment. Res. 68, 540-555.

Bhattacharya, J.P., MacEachern, J.A., 2009. Hyperpycnal rivers and prodeltaic shelves in the Cretaceous Seaway of North America. J. Sediment. Res. 79, 184-209.

Birgenheier, L.P., Horton, B., McCauley, A.D., Johnson, C.L., Kennedy, A., 2017. A depositional model for offshore deposits of the lower Blue Gate Member, Mancos Shale, Uinta Basin, Utah, USA. Sedimentology 64, 1402-1438.

Bouma, A.H., 1962. Sedimentology of Some Flysch Deposits: A Graphic Approach to Facies Interpretation. Elsevier, Amsterdam, Netherlands 168 pp.

Buatois, L.A., Mángano, M.G., 2011. Ichnology Organism-Substrate Interactions in Space and Time. Cambridge University Press, New York 358 pp.

Buatois, L.A., Mángano, M.G., Pattison, S.A., 2019. Ichnology of prodeltaic hyperpycniteturbidite channel complexes and lobes from the Upper Cretaceous Prairie Canyon Member of the Mancos Shale, Book Cliffs, Utah, USA. Sedimentology https://doi.org/ $10.1111 /$ sed.12560.

Canale, N., Ponce, J.J., Carmona, N.B., Drittanti, D.I., Olivera, D.E., Martínez, M.A., Bournod, C.N., 2015. Sedimentología e icnología de deltas fluvio-dominados afectados por descargas hiperpícnicas de la Formación Lajas (Jurásico Medio), Cuenca Neuquina, Argentina. Andean Geol. 42, 114-138.

Carbone, O., Franzese, J., Limeres, M., Delpino, D., Martínez, R., 2011. El Ciclo Precuyano (Triásico Tardío-Jurásico Temprano) en la Cuenca Neuquina. In: Leanza, H.A., et al. (Eds.), Relatorio Del XVIII Congreso Geológico Argentino, pp. 63-76.

Catuneanu, O., 2006. Principles of Sequence Stratigraphy. Elsevier 375 pp.

DeReuil, A.A., Birgenheier, L.P., 2019. Sediment dispersal and organic carbon preservation in a dynamic mudstone-dominated system, Juana Lopez Member, Mancos Shale. Sedimentology 66, 1002-1041 https://doi.org/10.1111/sed.12532.

Desjardins, P., Fantín, M., González Tomassini, F., Reijenstein, H., Sattler, F., Domínguez, F. Kietzmann, D. Bande, A., Benoit, S., Borgnia, M. Vittore, F, Simo, T., Minisini, D, 2016. Capitulo 2: Estratigrafía Sísmica Regional. In: González, G., et al. (Eds.), Transecta Regional de la Formación Vaca Muerta, IAPG, pp. 5-22.

Digregorio, J.H., 1972. Neuquén. In: Leanza, A.F., (Ed.), Geología Regional Argentina, Academia Nacional de Ciencias. Córdoba 439-505.

Domínguez, R.F., Paulin, S., Continanzia, M.J., Askenazi, A.D., Seoane, F.N., 2014 Estratigrafía del intervalo Vaca Muerta-Quintuco en el sector central de la Cuenca Neuquina. IX Congreso de Exploración y Desarrollo de Hidrocarburos, Mendoza, Argentina, pp. 231-250.

Dominguez, R.F., Reijenstein, H., Kohler, G., Sattler, F., Moreno, M., Gomez Rivarola, L., Borgnia, M., 2017. Distribución regional de quiebres de clinoformas del sistema Vaca Muerta-Quintuco. XX Congreso Geológico Argentino, Geología de la Formación Vaca Muerta, San Miguel de Tucumán, Argentina, pp. 38-45.

Edwards, D.A., Leeder, M.R., Best, J.L., Pantin, H.M. 1994. On experimental reflected density currents and the interpretation of certain turbidites. Sedimentology 41 , $437-461$

Eschner, T.B., Kocurek, G., 1986. Marine destruction of eolian sand seas: origin of mass flows. J. Sediment. Petrol. 56, 401-411.
Freije, H., Azúa, G., González, R., Ponce, J.J. Zavala, C.A., 2002. Actividad tectónica sinsedimentaria en el Jurásico del sur de la Cuenca Neuquina. In. V. Congreso de Exploración y Desarrollo de Hidrocarburos, Mar del Plata, Argentina, p. 17.

Fryberger, S.G., Krystinik, L.F., Schenk, C.J., 1990. Tidally flooded back-barrier dunefield, Guerrero Negro area, Baja California, Mexico. Sedimentology 37, 23-43.

Gabbott, S.E., Zalasiewicz, J., Aldridge, R.J., Theron, J.N., 2010. Eolian input into the Late Ordovician postglacial Soom Shale, South Africa. Geology 38, 1103-1106. https://doi. org/10.1130/G31426.1.

Gilbert, G.K., 1885. The topographic features of lake shores. U.S. Geol. Surv. Annu. Rep. 5, 104-108.

González, G., Vallejo, M.D., Kietzmann, D.A., Marchal, D., Desjardins, P.R., González Tomassini, F., Gómez Rivarola, L., Domínguez, R.F., Fantín, M.A., 2016. Transecta Regional de la Formación Vaca Muerta. IAPG 252 pp.

Gulisano, C., 1981. El ciclo Cuyano en el norte de Neuquén y sur de Mendoza. $8^{\circ}$ Congreso Geológico Argentino, Actas 3, San Luis, Argentina, pp. 579-592.

Gulisano, C.A., Gutiérrez Pleimling, A.R., Digregorio, R.E., 1984. Análisis estratigráfico del intervalo Tithoniano-Valanginiano (Formaciones Vaca Muerta, Quintuco y Mulichinco) en el suroeste de la provincia de Neuquén. IX Congreso Geológico Argentino, Actas I, Bariloche, Argentina, In, pp. 221-235.

Hedges, JI., Keil, R.G., 1995. Sedimentary organic matter preservation: an assessment and speculative synthesis. Mar. Chem. 49, 81-115. https://doi.org/10.1016/0304-4203 (95)00008-F.

Helland-Hansen, W., Hampson, G.J., 2009. Trajectory analysis: concepts and applications. Basin Res. 21, 454-483.

Higgs, R., 2004. Ross and Bude Formations (Carboniferous, Ireland and England): reinterpreted as lake-shelf turbidites. J. Pet. Geol. 27 (1), 47-66.

Hill, P.S., Fox, J.M., Crockett, J.S., Curran, K.J., Friedrichs, C.T., Geyer, W.R., Milligan, T.G., Ogston, A.S., Puig, P., Scully, M.E., Traykovski, P.A., 2007. Sediment delivery to the seabed on continental margins. In: Nittrouer, C.A., et al. (Eds.), Continental Margin Sedimentation: From Sediment Transport to Sequence Stratigraphy. Int. Assoc. Sedimentol. Spec. Publ. 37, pp. 49-99.

Hine, A.C., 1977. Lily Bank, Bahamas: history of an active oolite sand shoal. J. Sediment. Res., 47, 1554-1581. https://doi.org/10.1306/212F73B5-2B24-11D7-8648000102C1865D.

Howell, J.A., Schwarz, E., Spalletti, L.A., Veiga, G.D., 2005. The Neuquén Basin: an overview. In: Veiga, G.D., et al. (Eds.). The Neuquén Basin, Argentina: A Case Study in Sequence Stratigraphy and Basin Dynamics, Geological Society of London 252, 1-14.

Katz, B.J., 2005. Controlling factors on soure rock development - a review of productivity, preservation, and sedimentation rate. In: Harris, N.B., (Ed.). The Deposition of Organic-Carbon-Rich Sediments: Models, Mechanisms, and Consequences, SEPM Special Publication 82, 7-16.

Kendall, C.G.S.C., Schlager, W., 1981. Carbonates and relative changes in sea level. Mar. Geol. 44, 181-212. https://doi.org/10.1016/0025-3227(81)90118-3.

Kneller, B., 1995. Beyond the turbidite paradigm: physical models for deposition of turbidites and their implications for reservoir prediction. Geol. Soc. Lond. Spec. Publ. 94, $31-49$.

Kneller, B.C., Bennett, S.J., McCaffrey, W.D., 1997. Velocity and turbulence structure of density currents and internal solitary waves: potential sediment transport and the formation of wave ripples in deep water. Sediment. Geol. 112, 235-250.

Könitzer, S.F., Davies, S.J., Stephenson, M.H., Leng, M.J., 2014. Depositional controls on mudstone lithofacies in a basinal setting: implications for the delivery of sedimentary organic matter. J. Sediment. Res. 84, 198-214. https://doi.org/10.2110/ jsr.2014.18.

Krim, N., Bonnel, C., Tribovillard, N., Imbert, P., Aubourg, C., Riboulleau, A., BoutRoumazeilles, V., Hoareau, G. Fasentieux, B. 2017. Paleoenvironmental evolution of the southern Neuquèn basin (Argentina) during the Tithonian-Berriasian (Vaca Muerta and Picún Leufú Formations): a multi-proxy approach. Bull. la Société géologique Fr. 188 (34), 1-33.

Kuenen, P., 1960. Experimental abrasion 4: eolian action. J. Geol. 68, 427-449,

Lamb, M.P., Myrow, P.M., Lukens, C., Houck, K., Strauss, J., 2008. Deposits from waveinfluenced turbidity currents: Pennsylvanian Minturn Formation, Colorado, U.S.A. J. Sediment. Res. 78, 480-498.

Lash, G.G., 2016. Hyperpycnal transport of carbonaceous sediment - example from the Upper Devonian Rhinestreet Shale, western New York, U.S.A. Palaeogeogr. Palaeoclimatol. Palaeoecol. 459, 29-43. https://doi.org/10.1016/j.palaeo.2016.06.035.

Lazar, O.R., Bohacs, K.M., Macquaker, J.H.S., Schieber, J., Demko, T.M., 2015. Capturing key attributes of fine-grained sedimentary rocks in outcrops, cores, and thin sections: nomenclature and description guidelines. J. Sediment. Res. 85, 230-246.

Leanza, H.A., 1973. Estudio sobre los cambios faciales de los estratos limítrofes JurásicoCretácicos entre Loncopué y Picún Leufú, provincia de Neuquén, República Argentina. Rev. Asoc. Geol. Argent. 28 (2), 97-132.

Leanza, H.A. Hugo, C.A., 1977. Sucesión de amonites y edad de la Formación Vaca Muerta y sincrónicas entre los paralelos $35^{\circ}$ y $40^{\circ}$ l.s., Cuenca Neuquina-Mendocina. Rev. Asoc. Geol. Argentina 32, 248-264.

Leanza, H.A., Sattler, F., Martinez, R.S., Carbone, O., 2011. La Formación Vaca Muerta y equivalentes (Jurásico Tardío-Cretácico Temprano) en la Cuenca Neuquina. In: Leanza, H.A., et al. (Eds.), Relatorio Del XVIII Congreso Geológico Argentino, pp. $113-130$.

Legarreta, L, Gulisano, C. 1989. Análisis estratigráfico secuencial de la Cuenca Neuquina (Triásico Superior - Terciario Inferior), Argentina. In: Chebli, G.A., Spalletti, L.A., (Eds.). Cuencas Sedimentarias Argentinas, Serie Correlación Geológica 6, 221-243.

Ma, Y. Wright L.D., Friedrichs, C. 2008, Observations of sediment transport on the continental shelf off the mouth of the Waiapu River, New Zealand: evidence for currentsupported gravity flows. Cont. Shelf Res. 28, 516-532.

MacEachern, J.A., Gingras, M.K., 2007. Recognition of brackish-water trace-fossil suites in the Cretaceous Western Interior Seaway of Alberta, Canada. In: Bromley, R.G., et al. 
(Eds.), Sediment-Organism Interactions; A Multifaceted Ichnology, SEPM Spec. Publ 88, 149-193.

Macquaker, J.H.S., Keller, M.A., Davies, S.J., 2010. Algal blooms and "marine snow": mechanisms that enhance preservation of organic carbon in ancient fine-grained sediments. J. Sediment. Res. 80, 934-942. https://doi.org/10.2110/jsr.2010.085.

Massaferro, J.L., Zeller, M., Giunta, D.L., Sagasti, G., Eberli, G.P., 2014. Evolución del sistema mixto Tithoniano-Valanginiano (Formaciones Vaca Muerta, Quintuco y equivalentes) a partir de estudios de afloramientos y subsuelo, centro-sur de la Cuenca Neuquina. IX Congreso de Exploración y Desarrollo de Hidrocarburos, Mendoza, Argentina, In, pp. 251-274.

Mitchum, R.M.J., Uliana, M.A., 1985. Seismic stratigraphy of carbonate depositional sequences, Upper Jurassic-Lower Cretaceous, Neuquén Basin, Argentina. In: Berg, O. Woolverton, D., (Eds.), Seismic Stratigraphy II: An Integrated Approach to Hydrocarbon Exploration, AAPG, pp. 255-274.

Mpodozis, C., Ramos, V.A., 2008. Tectónica jurásica en Argentina y Chile: extensión, subducción oblicua, rifting, deriva y colisiones? Rev. Asoc. Geol. Argent. 63 (4), 481-497.

Mulder, T., Alexander, J., 2001. The physical character of subaquaeous sedimentary density flows and their deposits. Sedimentology 48, 269-299.

Mulder, T., Chapron, E., 2011. Flood deposits in continental and marine environments: character and significance. In: Slatt, R.M., Zavala, C.A., (Eds.). Sediment Transfer from Shelf to Deep Water-Revisiting the Delivery System, AAPG Studies in Geology 61, 1-30.

Mulder, T., Syvitski, J.P.M., 1995. Turbidity currents generated at river mouths during exceptional discharges to the world oceans. J. Geol. 103, 285-299.

Mulder, T., Syvitski, J.P.M., Migeon, S., Faugeres, J.C., Savoye, B., 2003. Marine hyperpycnal flows: initiation, behavior and related deposits. A review. Mar. Pet. Geol. 20, 861-882.

Mutti, E., Davoli, G., Tinterri, R., Zavala, C.A., 1996. The importance of ancient fluvio-deltaic systems dominated by catastrophic flooding in tectonically active basins. Mem. di Sci. Geol. 48, 223-291.

Mutti, E., Normark, W.R., 1991. An integrated approach to the study of turbidite systems. In: Weimer, P., Link, M.H. (Eds.), Seismic Facies and Sedimentary Processes of Submarine Fans and Turbidite Systems. Springer-Verlag, New York, pp. 75-106.

Mutti, E., Sonnino, M., 1981. Compensation cycles: a diagnostic feature of turbidite sandstone lobes. International Association of Sedimentologists, 2nd European Regional Meeting, Abstracts. Bologna, Italy, pp. 120-123.

Myrow, P.M., Fischer, W., Goodge, J.W., 2002. Wave-modified turbidites: combined-flow shoreline and shelf deposits, Cambrian, Antarctica. J. Sediment. Res. 72, 641-656.

Myrow, P.M., Lukens, C., Lamb, M.P., Houck, K., Strauss, J., 2008. Dynamics of a transgressive prodeltaic system: implications for geography and climate within a Pennsylvanian Intracratonic Basin, Colorado, U.S.A. J. Sediment. Res. 78, 512-528.

Myrow, P.M., Southard, J.B., 1996. Tempestite deposition. J. Sediment. Res. 66 (5), 875-887.

Naipauer, M., García Morabito, E., Marques, J.C., Tunik, M., Rojas Vera, E.A., Vujovich, G.I., Pimentel, M.P., Ramos, V.A., 2012. Intraplate Late Jurassic deformation and exhumation in western central Argentina: constraints from surface data and U-Pb detrital zircon ages. Tectonophysics 524-525, 59-75.

Noffke, N., 2010. Geobiology. Microbial Mats in Sandy Deposits from the Archaean Era to Today. Springer, Heidelberg 194 pp.

Notta, R., Davogustto, O., Desjardins, P., Williams, B., 2017. Slump deposits identification in low angle carbonate ramp settings, Cruz de Lorena (Neuquén Basin, Argentina): towards an integrated model explaining anomalous water recovery and poor well performance. XX Congreso Geológico Argentino, Geología de la Formación Vaca Muerta, San Miguel de Tucumán, Argentina, In, pp. 91-96.

Otharán, G.A., Zavala, C.A., Zorzano, A., 2016. Los depósitos turbidíticos de la Formación Vaca Muerta (Jurásico tardío-Cretácico temprano) al sur de la Dorsal de Huincul, Neuquén, Argentina. VI Simposio Argentino del Jurásico, Malargüe, p. 29.

Otharán, G.A., Zavala, C., Arcuri, M., 2017. Las turbiditas de la Formación Vaca Muerta (Tithoniano) en la subcuenca de Picún Leufú, Cuenca Neuquina. Argentina. In, XX Congreso Geológico Argentino, Geología de la Formación Vaca Muerta, San Miguel de Tucumán, Argentina, pp. 103-109.

Otharán, G.A., Zavala, C.A., 2016. Reconocimiento de turbiditas fangosas en la Formación Vaca Muerta (Jurásico Tardío-Cretácico Temprano), Neuquén, Argentina. In. VI. Simposio Argentino del Jurásico, Malargüe, Argentina, p. 30.

Otharán, G.A., Zavala, C.A., 2018. Muddy hyperpycnal flows and organic-rich shales. The Upper Jurassic - Lower Cretaceous Vaca Muerta Formation, Neuquen Basin. XX International Sedimentological Conference, Quebec City, Argentina. In.

Paim, P.S.G., Correa, E.L.C., Faccini, U.F., 2011. Fluvial-derived turbidites in the Los Molles Formation (Jurassic of the Neuquén Basin): initiation, transport, and deposition, In: Slatt, R.M., Zavala, C.A., (Eds.). Sediment Transfer from Shelf to Deep WaterRevisiting the Delivery System, AAPG Studies in Geology 61, 95-116.

Parent, H., Garrido, A.C., Schweigert, G., Scherzinger, A., 2011. The Tithonian ammonite fauna and stratigraphy of Picún Leufú, southern Neuquén Basin. Argentina. Rev. Paleobiol. 30, 45-104.

Patruno, S., Hampson, G.J., Jackson, C.A.L., 2015. Quantitative characterisation of deltaic and subaqueous clinoforms. Earth-Science Rev. 142, 79-119.

Pattison, S., 2005. Storm-influenced prodelta turbidite complex in the lower Kenilworth Member at Hatch Mesa, Book Cliffs, Utah, U.S.A.: implications for shallow marine facies models. J. Sediment. Res. 75, 420-439.

Pattison, S.A., Hoffman, T.A., 2008. Sedimentology, architecture and origin of shelf turbidite bodies in the Upper Cretaceous Kenilworth Member, Book Cliffs, Utah, USA. In: Recent Advances in Models on Siliciclastic Shallow-marine Stratigraphy (Ed. G.J. Hampson). SEPM Spec. Publ. 90, 391-420.

Pattison, S.A.J., Ainsworth, R.B., Hoffman, T.A., 2007. Evidence of across-shelf transport of fine-grained sediments: turbidite-filled shelf channels in the Campanian Aberdeen Member, Book Cliffs, Utah, USA. Sedimentology 54, 1033-1063.

Pirmez, C., Pratson, L.F., Steckler, M.S., 1998. Clinoform development by advectiondiffusion of suspended sediment: modeling and comparison to natural systems. J. Geophys. Res. 103, 24,141-24,157.
Playton, T., Janson, X., Kerans, C., 2010. Carbonate slopes. In: James, N.P., Dalrymple, R.W. (Eds.), Facies Models 4. Geological Association of Canada, pp. 449-476.

Plink-Bjölrklund, P., Steel, R.J., 2004. Initiation of turbidity currents: outcrop evidence for Eocene hyperpycnal flow turbidites. Sediment. Geol. 165, 29-52.

Plint, A.G., 2010. Wave-and storm-dominated shoreline and shallow-marine systems. In: James, N.P., Dalrymple, R.W., (Eds.). Facies Models 4, 167-200.

Ponce, J.J., Carmona, N., Wetzel, A., Paz, M., 2016. Sedimentología e Icnología del tramo basal de la Formación Vaca Muerta, Cuenca Neuquina, Argentina: Implicancias en el análisis de la transgresión del Tithoniano. $7^{\circ}$ Latin American Congress of Sedimentology and 15th Argentinean Meeting of Sedimentology. Santa Rosa, Argentina, p. 136

Ponce, J.J., Carmona, N.B., 2011a. Coarse-grained sediment waves in hyperpycnal clinoform systems, Miocene of the Austral foreland basin, Argentina. Geology 39, 763-766.

Ponce, J.J., Carmona, N.B., 2011b. Miocene deep-marine hyperpycnal channel levee complexes, Tierra del Fuego, Argentina: facies associations and architectural elements. In: Slatt, R.M., Zavala, C.A., (Eds.). Sediment Transfer from Shelf to Deep WaterRevisiting the Delivery System, AAPG Studies in Geology 61, 75-93.

Ponce, J.J., Carmona, N.B., Montagna, A., Canale, N., 2015. Sedimentología e icnología de los sistemas petroleros no convencionales de la Cuenca Neuquina. Guia de Campo. Universidad Nacional de Río Negro - Fundación YPF.

Ponce, J.J., Olivero, E.B., Martinioni, D.R., 2008. Upper Oligocene-Miocene clinoforms of the foreland Austral Basin of Tierra del Fuego, Argentina: stratigraphy, depositional sequences and architecture of the foredeep deposits. J. S. Am. Earth Sci. 26, 36-54.

Posamentier, H.W., Jervey, M.T., Vail, P.R., 1988. Eustatic controls on clastic deposition Iconceptual framework. In: Wilgus, C.K., et al., (Eds.), Sea-Level Changes-An Integrated Approach, SEPM Spec. Publ. 42, 109-124.

Posamentier, H.W., Vail, P.R., 1988. Eustatic controls on clastic deposition II-sequence and systems tract models. In: Wilgus, C.K., et al., (Eds.), Sea-Level Changes - An Integrated Approach. SEPM Spec. Publ. 125-154.

Pose, F., Gangui, A., Galeazzi, S., 2014. Estratigrafia secuencial del sistema Quintuco-Vaca Muerta en el engolfamiento neuquino, Cuenca Neuquina, Argentina. IX Congreso de Exploración y Desarrollo de Hidrocarburos, Simposio de Recursos No Convencionales, Mendoza, Argentina, In, pp. 211-229.

Prélat, A., Hodgson, D.M., 2013. The full range of turbidite bed thickness patterns in submarine lobes: controls and implications. J. Geol. Soc. Lond. 170, 209-214.

Ramos, V.A., Folguera, A., 2005. Tectonic evolution of the Andes of Neuquén: constraint derived from the magmatic arc and foreland deformation. In: Veiga, G.D. et al., (Eds.). The Neuquén Basin, Argentina: A Case Study in Sequence Stratigraphy and Basin Dynamics, Geological Society of London 252, 15-35.

Reijenstein, H., Lanusse, I., Oviedo, P., Licitra, D., Sotelo, D., Vittore, F., Quiroga, J., González Tomassini, F., 2017. ¿Deslizamientos en Vaca Muerta? Observaciones e integración de datos sísmicos, pozos y coronas en el yacimiento Loma Campana, Cuenca Neuquina, Argentina. XX Congreso Geológico Argentino, Geología de la Formación Vaca Muerta. San Miguel de Tucumán, Argentina, pp. 122-129.

Reijenstein, H.M., Posamentier, H.W., Fantín, M.A., González Tomassini, F., Lipinski, C. 2014. Vaca Muerta seismic stratigraphy and geomorphology: regional architectura trends for unconventional exploration. IX Congreso de Exploración y Desarrollo de Hidrocarburos, Abstracts Extendidos, Mendoza, Argentina, In, pp. 211-220.

Riccardi, A.C., 2008. El Jurásico de la Argentina y sus amonites. Rev. Asoc. Geol. Argent. 63 625-643.

Riccardi, A.C., 2015. Remarks on the Tithonian-Berriasian ammonite biostratigraphy of west central Argentina. Vol. Jurassica 13, 23-52.

Röhl, H.J., Schmid-Röhl, A., Oschmann, W., Frimmel, A., Schwark, L., 2001. The Posidonia Shale (Lower Toarcian) of SW Germany: an oxygen depleted ecosystem controlled by sea level and paleoclimate. Palaeogeogr. Palaeoclimatol. Palaeoecol. 165, 27-52.

Sageman, B.B., Murphy, A.E., Werne, J.P., Ver Straeten, C.A., Hollander, D.J., Lyons, T.W. 2003. A tale of shales: the relative roles of production, decomposition, and dilution in the accumulation of organic-rich strata, Middle-Upper Devonian, Appalachian basin. Chem. Geol. 195, 229-273. https://doi.org/10.1016/S0009-2541(02)00397-2.

Santiago, M.F., Rauzi, R.S., Laffitte, G.A., Alvarado, O.A., 2014. La Formación Vaca Muerta como objetivo exploratorio no convencional en la subcuenca de Picún Leufú. Neuquén, Argentina. In: IX Congreso de Exploración y Desarrollo de Hidrocarburos, Simposio de Recursos No Convencionales, Mendoza, Argentina, pp. 275-314.

Savrda, C.E., Bottjer, D.J., 1987. The exaerobic zone, a new oxygen-deficient marine biofacies. Nature 327, 54-56

Schieber, J., 1986. The possible role of benthic microbial mats during the formation of car bonaceous shales in shallow Mid-Proterozoic basins. Sedimentology 33, 521-536.

Schieber, J., 2007. Microbial mats on muddy substrates - Examples of possible sedimentary features and underlying processes. In: Schieber, J., et al. (Eds.), Atlas of Microbia Mat Features Preserved within the Siliciclastic Rock Record, Elsevier, pp. 117-134.

Schlager, W., 2005. Carbonate sedimentology and sequence stratigraphy. SEPM, Concepts in Sedimentology and Paleontology No. 8200 pp.

Snedden, J.W., Dalrymple, R.W., 1999. Modern shelf sand bodies: from historical perspective to a unified theory for sand body genesis and evolution. In: Bergman, K.M. Snedden, J.D., (Eds.), Isolated Shallow Marine Sand Bodies: Sequence Stratigraphic Analysis and Sedimentologic Interpretation. SEPM Spec. Publ. 64, 13-28.

Snedden, J.W., Nummedal, D., 1990. Coherence of surf zone and shelf current flow on the Texas (USA) coastal margin: implications for interpretation of paleocurrent measurements in ancient coastal sequences. Sediment. Geol. 67 (3-4), 221-236.

Spalletti, L.A., Franzese, J.R., Matheos, S.D., Schwarz, E., 2000. Sequence stratigraphy of a tidally dominated carbonate-siliciclastic ramp; the Tithonian-Early Berriasian of the Southern Neuquén Basin, Argentina. J. Geol. Soc. Lond. 157, 433-446.

Sparks, R.S.J., Bonnecaze, R.T., Huppert, H.E., Lister, J.R., Hallworth, M.A., Mader, H., Phillips, J., 1993. Sediment-laden gravity currents with reversing buoyancy. Earth Planet. Sci. Lett. 114, 243-257. 
Steel, E., Simms, A.R., Warrick, J., Yokoyama, Y., 2016. Highstand shelf fans: the role of buoyancy reversal in the deposition of a new type of shelf sand body. Bull. Geol. Soc. Am. 128, 1717-1724.

Steel, R., Olsen, T., 2002. Clinoforms, clinoform trajectories and deepwater sands. In: 22nd Annual Gulf Coast Section, pp. 367-380.

Stipanicic, P.N., Rodrigo, F., Baulies, O.L., Martínez, C.G., 1968. Las Formaciones presenonianas en el denominado Macizo Nordpatagónico y regiones adyacentes. Rev. Asoc. Geol. Argent. 23 (2), 67-98.

Swenson, J.B., Paola, C., Pratson, L., Voller, V.R., Murray, A.B., 2005. Fluvial and marine controls on combined subaerial and subaqueous delta progradation: morphodynamic modeling of compound-clinoform development. J. Geophys. Res. Earth Surf. 110, 1-16.

Swift, D.J.P., Han, G., Vincent, C.E., 1986. Fluid processes and sea-floor response on a modern storm-dominated shelf: middle Atlantic Shelf of North America. Part I: the stormcurrent regime. In: Knight, R.J., Ross Mclean, J., (Eds.). Shelf Sands and Sandstones, AAPG Memoir 11, 99-119.

Taylor, A.M., Goldring, R., 1993. Description and analysis of bioturbation and ichnofabric. J. Geol. Soc. Lond. 150, 141-148.

Tucker, M.E., Wright, V.P., 1990. Carbonate Sedimentology. John Wiley \& Sons 482 pp.

Tunik, M., Folguera, A., Naipauer, M., Pimentel, M., Ramos, V.A., 2010. Early uplift and orogenic deformation in the Neuquén Basin: Constraints on the Andean uplift from $\mathrm{U}-\mathrm{Pb}$ and $\mathrm{Hf}$ isotopic data of detrital zircons. Tectonophysics 489, 258-273.

Tyson, R.V., 2005. The "productivity versus preservation" controversy: cause, flaws, and resolution. In: Harris, N.B. (Ed.), The Deposition of Organic-Carbon-Rich Sediments: Models. 82, pp. 17-33 Mechanisms, and Consequences, SEPM Special Publication.

Uliana, M.A., Legarreta, L., Laffitte, G.A., Villar, H., 1999. Estratigrafía y geoquímica de las facies generadoras de hidrocarburos en las Cuencas Petrolíferas de Argentina. In: $4^{\circ}$ Congreso de Exploración y Desarrollo de Hidrocarburos. Plata, Argentina, Trabajos Técnicos. Simposio de Sistemas Petroleros de las Cuencas Argentinas. CD ROM. Mar del.

Veiga, G.D., Spalletti, L.A., 2007. The Upper Jurassic (Kimmeridgian) fluvial-aeolian systems of the southern Neuquén Basin, Argentina. Gondwana Res. 11, 286-302.

Wang, H., Ma, F., Tong, X., Liu, Z., Zhang, X., Wu, Z., Li, D., Wang, B., Xie, Y., Yang, L., 2016 Assessment of global unconventional oil and gas resources. Pet. Explor. Dev. 43, 925-940. https://doi.org/10.1016/S1876-3804(16)30111-2.

Warrick, J.A., Simms, A.R., Ritchie, A., Steel, E., Dartnell, P., Conrad, J.E., Finlayson, D.P., 2013. Hyperpycnal plume-derived fans in the Santa Barbara Channel, California. Geophys. Res. Lett. 40, 2081-2086. https://doi.org/10.1002/grl.50488.

Williams, H.D., Burgess, P.M., Wright, V.P., Della Porta, G., Granjeon, D., 2011. Investigating carbonate platform types: multiple controls and a continuum of geometries. J. Sediment. Res. 81, 18-37.

Wilson, R.D., Schieber, J., 2014. Muddy prodeltaic hyperpycnites in the Lower Genesee Group of Central New York, USA: implications for mud transport in epicontinental seas. J. Sediment. Res. 84, 866-874. https://doi.org/10.2110/jsr.2014.70.

Wright, A.L.D., Nittrouer, C.A., 1995. Dispersal of river sediments in coastal seas: six contrasting cases. Estuaries 18, 494-508.

Wright, L.D., 2012. Recent advances in understanding continental shelf sediment transport. In: Li, M.Z et al. (Eds.), Sediments, Morphology and Sedimentary Processes on Continental Shelves. Int. Assoc. Sedimentol. Spec. Publ. 44, 159-172.
Wright, L.D., Friedrichs, C.T., 2006. Gravity-driven sediment transport on continental shelves: a status report. Cont. Shelf Res. 26, 2092-2107.

Wright, L.D., Friedrichs, C.T., Kim, S.C., Scully, M.E., 2001. Effects of ambient currents and waves on gravity-driven sediment transport on continental shelves. Mar. Geol. 175, $25-45$.

Wright, V.P., 1992. A revised classification of limestones. Sediment. Geol. 76 (3-4), $177-185$.

Yawar, Z., Schieber, J., 2017. On the origin of silt laminae in laminated shales. Sediment. Geol. 360, 22-34. https://doi.org/10.1016/j.sedgeo.2017.09.001.

Yose, L.A., Heller, P.L., 1989. Sea-level control of mixed carbonate-siliciclastic, gravity-flow deposition: lower part of the Keeler Canyon Formation (Pennsylvanian), southeastern California. Geol. Soc. Am. Bull. 101, 427-439.

Zavala, C.A., Arcuri, M., 2016. Intrabasinal and extrabasinal turbidites: origin and distinctive characteristics. Sediment. Geol. 337, 36-54.

Zavala, C.A. Arcuri, M., Blanco Valiente, L, 2012. The importance of plant remains as diagnostic criteria for the recognition of ancient hyperpycnites. Rev. Paleobiol. Vol. spec. 11, 457-469.

Zavala, C.A., Arcuri, M., Di Meglio, M., Gamero Diaz, H., Contreras, C., 2011. A genetic facies tract for the analysis of sustained hyperpycnal flow deposits. In: Slatt, R.M., Zavala, C.A., (Eds.). Sediment Transfer from Shelf to Deep Water-Revisiting the Delivery System, AAPG Studies in Geology 61, 31-51.

Zavala, C.A. Freije, H., 2002. Cuñas clásticas jurásicas vinculadas a la Dorsal de Huíncul. Un ejemplo del area de Picun Leufu. Cuenca Neuquina, Argentina. In: V Congreso de Exploración y Desarrollo de Hidrocarburos, Mar del Plata, Argentina, pp. 1-14.

Zavala, C.A., Lampe, J.M.M., Fernández, M., Di Meglio, M., Arcuri, M., 2008. El diacronismo entre las formaciones Tordillo y Quebrada del Sapo (Kimeridgiano) en el sector sur de la cuenca Neuquina. Rev. Asoc. Geol. Argent. 63, 754-765.

Zavala, C.A., Maretto, H., Di Meglio, M., 2005. Hierarchy of bounding surfaces in aeolian sandstones of the Jurassic Tordillo Formation (Neuquén Basin, Argentina). Geol. Acta 3, 133-145.

Zeller, M., 2013. Facies, Geometries and Sequence Stratigraphy of the Mixed Carbonate Siliciclastic Quintuco - Vaca Muerta System in the Neuquén Basin, Argentina: An Integrated Approach (PhD Thesis). Open Access Diss. Thesis, University of Miami 206 pp.

Zeller, M., Eberli, G.P., Weger, R.J., Giunta, D.L., Massaferro, J.L., 2014. Seismic Expressions of the Quintuco-Vaca Muerta System Based on Outcrop Facies and Geometry. IX Congreso de Exploración y Desarrollo de Hidrocarburos, Mendoza, Argentina, pp. 209-224.

Zeller, M., Reid, S.B., Eberli, G.P., Weger, R.J., Massaferro, J.L., 2015a. Sequence architecture and heterogeneities of a field - scale Vaca Muerta analog (Neuquén Basin, Argentina) - from outcrop to synthetic seismic. Mar. Pet. Geol. 66, 829-847.

Zeller, M., Verwer, K., Eberli, G.P., Massaferro, J.L., Schwarz, E., Spalletti, L.A., 2015b. Depositional controls on mixed carbonate-siliciclastic cycles and sequences on gently inclined shelf profiles. Sedimentology 62, 2009-2037. 